\title{
Registro
}

\section{Relatorio referente ao anno de 1935}

\author{
RELATORIO DO DIRECTOR DA FACULDADE DE \\ DIREITO, DR. FRANCISCO MORATO.
}

Exmo. Sr. Governador,

Cumprindo um dos deveres que nos incumbem na direcção da Faculdade de Direito, vimos trazer ao conhecimento e censura de V. Exa. o relatorio annual dos trabalhos e movimento da Escola.

Ao nos investirmos nas honrosas funcções de Director, em data de 16 de maio de 1935, encontramos quasi totalmente demolido o velho casarão, onde por mais de um seculo funccionou a Academia, mulito avançada a construcção do novo edificio e já concluida a parte sobre a rua do Riachuelo, onde nos achamos installados.

Não nos foi possivel assim, nem salvar os remanescentes do tradicional convento de S. Francisco nem tampouco modificar nas suas linhas geraes a planta da nova edificação, de tal arte a afastal-a alguns metros da Igreja dos Franciscanos, como cumpria por bem e commodidade dos religiosos e da propria Faculdade.

Queremos assignalar este ponto afim de que fique para sempre registrado nosso sentimento de revolta, precisamente, como dissemos nas festas academicas de 11 de agosto proximo passado, no instante em que o camartello de um progresso inconsciente vem abafando os derradeiros echos das vozes dos varões illustres que por mais de um seculo encheram de luzes e harmonia as velhas cathedras e arcadas do glorioso Convento de S. Francisco.

$\mathrm{Si}$ houvera dependido de nós, nunca teriamos consentido na sinistra destruição de uma das mais preciosas reliquias da opulenta metropole paulistana; destruição de todo injustificavel, pois, si as necessidades do ensino e a expansão do movimento escolar reclamavam novas installações, bem se poderia attender a ellas, edificando-se aos lados e no fundo um arranha-céo, mantido o monumento onde se ouviram os primeiros vagidos de nossa independen- 
cia intellectual, magestoso na sua simplicidade, venerando na sua antiguidade, testemunha dos esplendores e esperanças que nos vêm acompanhando desde o alvorecer da nacionalidade, templo onde se apparelharam para engrandecer o nome da patria os vultos mais. notaveis na galeria dos brasileiros insignes.

Foi um attentado contra a tradição, attentado que felizmente não representa o pensamento, o genio e a cultura dos paulistas. Foi geral a indignação contra elle, como não podia deixar de ser, num meio onde se comprehende que um povo que não faz estima da tradição é um povo sem continuidade historica e sem consciencia de si mesmo.

Tanto que fomos investido em nossas funcções, volvemos para logo a attenção para os tres pontos culminantes da vida da Faculdade, no estado em que o deparamos, a saber, a disciplina academica, sob seus multiplos aspectos, assim em relação ao corpo docente e ao corpo discente, a este particularmente, a administração do Instituto e a construcção do novo eidificio.

Sentiamos, como sentiam todos, o imperioso dever de reerguer o nivel moral da velha academia, restaurando-lhe o prestigio, o renome e a efficacia de outr'ona; para o que vinham a ponto a opportunidade que as circumstancias offereciam.

Haviamos encerrado o hiato infelicissimo que uma longeva dictadura tinha aberto na normalidade consititucional do paiz; estava passado o lapso sombrio em que a escola se convertera em uma chancellaria de accessos e diplomas, outorgados a golpes de decretos e a beneplacito do poder executivo; era unanime entre as pessoas de senso e responsabilidade o sentimento de estupor e revolta em face da degradação do ensino, sacrificado pela audacia dos alumnos e pelo desinteresse com que a desordem geral por uma logica irreductivel contaminava os professores.

Sentia-se um novo sopro, em reacção decisiva contra o estiolamento da nobre causa. O espirito universitario que o Governo do Estado tão patrioticamente despertara; a solidariedade e firmeza com que os amigos da instrucção acudiram ao pensamento official, tudo contribuiu para crear um ambiente novo e a convicção generalizada que a Faculdade deixava de ser dirigida pelos alumnos e retomava o rythmo que nunca devera ter abandonado.

Normalizou-se a disciplina. A mocidade correspondeu docil e observante á boa vontade e devotamento dos professores, como sempre sóe acontecer. São os professores que fazem os bons alumnos. A mocidade é sempre a mocidade, cheia de vida, propensa á bohe- 
mia e entretimentos folgazões; mas quando o professor se esforça, cumpre a regra e honra a cathedra, a mocidade corresponde invariavelmente.

0 movimento de 1935 e as provas do anno demonstram que vae renascendo o espirito de disciplina academica e que dentro em breve poderemos nos ufanar do reflorescimento e retorno dos esplendores dos tempos idos.

\section{SITUAÇÃO JURIDICA E ORGANIZAÇĀO DIDACTICA DA FACULDADE}

Continúa a Faculdade na posição que lhe creou o decreto federal $\mathrm{n}^{\circ} 24.102$ de 10 de abril de 1934, transferindo-a ao Estado para os effeitos de incorporação á Universidade de S. Paulo. Continúa com o caracter de academia nacional, no goso de todas as prerogativas dos institutos officiaes congeneres da União, com seu patrimonio intangivel e inallienavel, sujeita á clausula de reversão á União si se extinguir a Universidade ou assim exigirem os interesses do ensino, assegurados aos seus antigos professores e funccionarios, ademais dos direitos e vantagens que se lhes outorgarem por leis estaduaes, aquelles e aquellas que lhes tocam pelas leis federaes, inclusive o recebimento de vencimentos do Thesouro Nacional.

Dos termos em que se fez a transferencia e da intangibilidade do patrimonio, inalienavel e applicado exclusivamente a seu beneficio, consoante reza o texto legal, resulta que a Faculdade ha-de sempre manter personalidade juridica propria de Acadiemia Nacional e a situação que occupa no Largo de S. Francisco, ao lado dos Franciscanos, que todos desejamos a acompanhem no futuro com as mesmas bençams e espirito de largueza com que lhe coderam o uso gratuito do magestoso casarão de sua séde e com que vem testemunhando, dia a dia atravez de cento e muitos annos, a prosperidade e esplendores de sua vida cultural.

Com a fundação da Universidade de S. Paulo, pensou-se em deslocal-a para o centro onde se imagina grupar todos os institutos que a compõem; pensamento a que com jusbos motivos é hostil a unanimidade da Congregação dos Professores, assim como a generalidade do corpo academico.

Nada de facto justificaria semelhante idéa. Si se tratasse de uma Universidade conjugando escollas novas, sem séde propria, comprehende-se que assim fosse, pois a vizinhança dos institutos e aggregação de seus edificios no mesmo sitio, além de realçarem o ponto de vista esthetico, facilitariam a unidade administrativa e pedagogica. Mas querer reunir em uma unica paragem ou zona escolas que possuem installações proprias em sitios diversos, sacrificando 
obras custosissimas e abafando tradições sagradas, que se prendem á terra como os rebentos ao tronco donde brotam, seria erro deploravel, ainda que a abastança do thesouro publico pudesse se afilar pela craveira de tamanhos desperdicios.

A propinquidade dos institutos não dá o estalão do espirito universitario, não é condição delle, nem mesmo quando pertencentes a um só patrimonio e pessoa juridica.

A famosa Universidade de Harvard, em Cambridge, Massachusetts, tem um centro onde se acham as repartições administrativas, alguns laboratorios, museus e bibliothecas, as Escolas de Direito, Artes e Sciencias, Theologia, Engenharia e outras. Mas fóra do centro, a distancias varias, demoram muitos de seus departamentos, pensionatos e collegios; as Escolas de Medicina, Hygiene Publica e Odontologia estão em Boston; a de Commercio, sobre o Charles River, que separa Cambridge de Boston.

A historica Universidade de Cambridge, na Inglaterra, é formada de um grupo de collegios ou escolas, que se disseninam de lado a lado da arteria principal da cidade, que, sob o nome de Trumpington Street e outros appellidos successivos, corta a povoação de sul a norte. O Christ's Collegie jaz distante, na Saint Andrew's Street; o Jesus College isola-se ao noroeste da maioria dos collegios.

A Universidade de Paris, cuja constituição actual è de data relativamente recente (1896), tem a sua séde, os serviços geraes e grande parte das Faculdades na Sorbonne. Entretanto, deparam-se afastadas as Faculdades de Direito e de Medicina, esta no Boulevard $S t=G e r m a i n$, aquella na Place du Panthéon.

Foi, pois, um pensamento infeliz, o dos que imaginaram deslocar a secular Academia. Infeliz, geralmente repugnado e por todos os motivos condemnado, sobretudo depois que se tem despendido centenas e centenas de contos de réis na nova edificação.

Felizmente, porém, constituem embaraço invencivel a semelhante idéa as clausulas de intangibilidade, inalienabilidade e destinação exclusiva a que o decreto de transferencia submetteu o patrimonio; clausulas que hão-de perdurar ainda que a Faculdade decaia no pleito judicial que lhe movem os Fransciscanos. Julgada sem o dominio do solo, não só ninguem lhe contestaria a propriedade do edificio senão que seria fatal a sequencia da desapropriação.

Quanto á organização dos cursos acha-se ella alterada, particularmente depois da lei $n$. 114 de 11 de novembro de 1935, modificativa da legislação do ensino.

Tornou-se facultativa nas Faculdades de Direito officiaes e nas reconhecidas pelo Governo Federal, a juizo das respectivas Con- 
gregações, a existencia do Curso de Doutorado. Transferiram-se delle para o curso de bacharelado as cadeiras de Direito Romano e de Direito Internacional Privado, devendo ser leccionadas, aquella no $10^{\circ}$ anno, esta no $5 .^{\circ}$. A cadeira de Sciencia das Finanças, do curso de doutorado passou para $02^{\circ}$ anno do curso de bacharelado, supprimida essa materia da $2 .^{\mathrm{a}}$ cadeira do $10^{\circ}$ anno deste curso, que em consequencia ficou sendo simplesmente de Economia Politica.

Usando da faculdade outorgada pela lei n. 114 de 1935, deliberou a Congregação supprimir o Curso de Doutorado.

A suppressão provocou um requerimento e pialavras de resalva de direitos da parte do professor Waldemar Ferreira.

Creado o Curso de Doutorado pelo decreto 6.429 de 9 de maio de 1934, foram nomeados os professores Vicente Ráo, Waldemar Ferreira, Sampaio Doria e Cardoso de Mello Netto para regerem respectivamente as cadeiras de Direito Publico, Historia do Direito Nacional, Economia e Legislação Social e Sciencia das Finanças; nomeações que se fizeram por decreto, sem concurso, poucos dias antes da promulgação da Constituição Federal de 16 de julho die 1934.

O professor Waldemar Ferreira, cuja situação é identica á dos outros nomeados pretende que, sem embargo da suppressão, perdurem seus direitos aos vencimentos e outras vantagens do cargo, por consequencia dos attributos de vitaliciedade e inamovibilidade com que fora investido nas funcções. Assim pretendendo e, ao mesmo tempo, reconhecendo não poder fazer jus de facto aos salarios da cathedra emquanto deputado federal, suggeriu, em requerimento ao Secretario da Educação, fosse posto em dłisponibilidade não remunerada, sem prejuizo dos demais direitos.

Em informações que acompanharam o requerimento, salientámos a improcedencia desse modo de ver e resalva.

Dispositivo nenhum de lei, decreto ou regulamento declarou vitalicios ou inamoviveis os nomeados. As nomeações foram feitas sem esses predicados, podendo, portanto, desapparecer ou annular-se com a suppressão do cargo, sem direito a reclamação ou consequencia nenhumai.

Nomeados por decreto, só exercem as funcções e auferem as vantagens correlatas emquanto não forem demittidos e perdurar os cargos; pelo que, si se restabelecer o curso, posto que provisoriamente, como póde acontiecer na conjunctura de que cogita a lei $\mathbf{n}$. 114 de 1935, de reclamarem vinte e cinco interessados ou os alumnos já inscriptos, volvem então ao exercicio das respectivas cathedras. Extincto ou suspenso, porem, o curso, não lhes assiste direito de especie alguma; são funccionarios cuja collação não se effectua com a clausula de estabilidade temporaria ou vitalicia. 
Foi sempre elementar na doutrina do direito publico e pacifico na jurisprudencia, que a vitaliciedade é uma excepção e que, como excepção, só se admitte quando expressa em lei (BARBALHO: Commentarios á Constituição, pag. 341. CARLOS MAXIMLIIANO: Commentarios á Constituiçẫo, 3.a ed. pag. 554, VIVEIROS DE CASTRO: Direito Administrativo, 3." ed. pag. 573.

Assim sempre foi no regimen da Constituição de 1891. Hoje é alguma coisa malis do que isso: além de não se presumir e de dever ser expressamente declarada em lei, a vitaliciedade de professor só é constitucionalmente possivel para os que o forem mediante concurso.

Está escripto no art. $158 \S 2 .^{\circ}$ da Constituição de 16 de julho de 1934.

Está escripto nos arts. 83 e 95 dos Estatutos da Universidade.

Está escripto no dec. 6.429 de 9 de maio de 1934, que expediu o primeiro regulamento da Faculdade depois de sua incorporação á Universidade e que creou o curso de doutorado. De facto, os cathedraticos que $o$ art. 49 do decreto declara vitalicios e inamoviveis são (sem contar os transferidos e os de merito excepcional, que não vêm ao caso) os que o art. 45 permitte para as cadeiras novas, mediante concurso no acto ou indicçção de professores já approvados em concurso da materia na Faculdade.

Está escripto no art. 46 do régulamento vigente da Faculdade (dec. 7.068 de 6 de abril de 1935), que reproduz as garantias de vitaliciedade e inamovibillidade na fórma da Constituição Federal, quer dizer, a beneficio dos nomeados por concurso (*).

\section{MOVIMENTO ADMINISTRATIVO E DIDACTICO}

Do relatorio annexo da Secretaria, a cargo do zeloso funccionario Flavio Mendes, constam circumstanciadamente todos os dados relativos ao movimento administrativo e didactico.

Exerceram a directoria nos primeiros mezes do anno, successivamente, de $10^{\circ}$ de janeiro a 16 de maio, data em que nos empossámos do cargo de director, os professores Waldemar Ferreira, Raphael Sampaio e Candido Motta.

Para vice-director elegeu o Conselho Technico-Administrativo, em sessão de 21 de Agosto, o professor Raphael Sampaio. Para mem. bros do Conselho Technico-Administrativo, do qual já faziam parte

(*) Esta materia foi sujeita pelo secretario da Educação ao Conselho Universitario que, em sessão de $17 / 4 / 36$ adoptou, por unanimidade de votos, o ponto de vista e parecer do Director da Faculdade, deliberando que os dictos professores não têm díreito a nenhuma vitaliciedade. 
os professores Raphael Sampaio e Gabriel de Rezende Filho, cujo manclato finda em 30 de agosto de 1936, na fórna regimental, foram norneados os professores Jorge Americano, Honorio Monteiro, Sampaio Doria e Mario Masagão, os dois primeiros em 14 de maio, os dois segundos em 8 de agosto.

A Congregação e o Conselho funccionaram com a devida regúlaridade.

Dada a quantidade de alumnos, desdobraram-se as aulas em todas as cadeiras, para maior efficiencia do ensino.

$\mathrm{Na}$ regencia das cathedras portaram-se os professores com o devotamento do costume e com o proveito que seria possivel em face do escasso periodo lectivo, reduzido na organização legal e reduzidissimo na pratica pelas interrupções de exames, concursos e feriados concedidos a proposito de tudo.

Na esphera administrativa, fizeram-se sentir providencias de necessidade immediata com o crescimento do corpo discente, hoje cifrado em cerca de 1.800 estudantes, com a creação do collegio universitario sem alteração do pessoal e com o augmento correspectivo de todos os serviços; donde as nomeações, promoções, substituições e contractos de que dá noticias detalhadas o relatorio.

A Revista da Faculdade não tem correspondido, nos ultimos tempos, á expectativa e ao alto prestigio de que gosou outr'ora, a despeito da competencia e zelo da commissão de redacção. Devese isso á falta de collaboração dos professores e á idéa infeliz de fazel-a trimestral. Cumpre publical-a apenas tres vezes por anno, afim de que tenha maior collaboração, feição mais interessante e cuidados mais assiduos nas secções de bibliographia, artigos de doutrina e monographias.

A $10^{\circ}$ de março houve uma sessão solemne de abertura dos cursos. Proferiu a prelecção inaugural o professor Alexandre Correia, dissertando sobre o thema "Direito Romano e Cultura Classica".

Revestiram-se de grande imponencia os festejos realizados em commemoração á data da abertura dos cursos juridicos no Brasili.

As solemnidades iniciaram-se pela manhã com uma missa rezada no pateo da antiga Academia, seguindo-se-lhe uma sessão commemorativa da data de XI de agosto.

No mesmo dia foi inaugurado o monumento mandado erigir em memoria dos academicos mortos na revolução de 32, doado á Faculdade de Direito pelo sr. Numa de Oliveira.

Encarregou-se, a convite dos academicos de direito, de proferir uma conferencia allusiva á data, o dr. Rodrigo Octavio, o qual, por motivo de molestia se fez representar pelo dr. Rodrigo Octavio Filho, que leu a conferencia "Era uma vez um convento". Falaram os professores Reynaldo Porchat e Francisco Morato, o dr. Alexandre Marcondes Filho, pela associação dos antigos alumnos da Far culdade, e diversos academicos. 
Estiveram presentes aos actos, além do dr. José Carlos de Macedo Soares, Ministro do Exterior, acompanhado do Consul Renato de Almeida, representante do Itamaraty, os Secretarios de Estado, Prefeito da Capital, Commandante da Força Publica e altas autoridades, dr. Reynaldo Porchat, Reitor da Universidade de São Paulo, dr. Francisco Morato, Director da Faculdade, Professor Leitão da Cunha, Reitor da Universidade do Rio de Janeiro, representantes da Imprensa Federal e Estadual.

A 14 de novembro celebrou-se sessão solemne de encerramento dos cursos, proferindo a respectiva prelecção o professor Anto. nio de Sampaio Doria, sobre o thema "Democracia, Liberdade e Justiça".

Varias foram as conferencias que se relalizaram no decurso do anno, para as quaes a Faculdade cedeu graciosamente os amphitheatros João Mendes Junior e Barão de Ramalho.

A Faculdade de Philosophia, Sciencias e Letras promoveu duas series dellas.

\section{1. ${ }^{a}$ serie}

PROFESSOR PIERRE HOURCADE (cadeira de Literatura Franceza) - Conferencias em 6,12 e 19 de agosto, 2, 9 e 16 de setembro sobre os themas: "Que é literatura? Analyse e rehabilitação de uma nação calumniada"; "Charles Baudelaire e Paul Verlaine, precursores do movimento poetico contemporaneo"; "A influencia franceza na literatura portugueza da segunda metade do seculo XIX"; "Guerra Junqueiro, sua época e Victor Hugo".

PROFESSOR AFFONSO DE E. TAUNAY (cadeira de Historia da Civilização Brasileira) -- Conferencias nos dias 20 de agosto, 3 e 17 de setembro, sobre "Bartholomeu de Gusmão e sua propriedade aerostatica".

PROFESSOR FRANCESCO PICCOLO (cadeira de Literatura Italiana) - Conferencias nos dias 13 de agosto, 10 e 24 de setembro, sobre: "Os Medici”; "A Casa dos Borgia"; "Um reformador do Seculo XIV (Savanarola)".

PROFESSOR PIERRE MONBEIG (cadeira de Geographia Physica e Humana) - Conferencias subordinadas ao titulo geral "Problemas geographicos do mundo moderno", nos dias 7, 14 e 28 de agosto, 4, 11 e 18 del setembro, assim discriminadas: 0 Rheno, arteria europea: a) "O rio e suas regiões"; b) "O Rheno de outr'ora; c) "A via economica" - "Superpopulação, fonte de conflictos"; "O problema da agua e da terra na Hespanha"; "Terras desbravadas". 
PROFESSOR CLAUDE LEVI-STRAUSS (cadeira de Sociologia) Conferencias sobre a crise do progresso, nos dias 8,15 e 22 de agosto, 5, 12 e 19 de setembro, assim desdobradas: Progresso e retrocesso; Os aspectos classicos da theoria do progresso; A crise do evolucionismo; A hypothese diffusionista; Existem culturas superiores?; A caminho de uma nova philosophia do progresso.

FROSESSOR MICHEL BERVEILLER (cadelira da Lingua e Literatura Grega e Latina) - Duas Conferencias, nos dias 23 e 30 de setembro: 0 latim, lingua universal; $O$ hellenismo de Paul Valéry.

PROFESSOR FELIX RAWITSCHER (cadeira de Botanica) - Uma conferencia, no dia 14 de setembro, sobre "O movimento das plantas trepadeiras", com a projecção de um filme organizado pelo proprio conferencista.

PROFESSOR FRANCISCO REBELLO GONÇALVES (cadeira de Philologia Portugueza) - Duas conferencias, nos dias 21 e 29 de setembro: A philologia portugueza contemporanea; 0 classicismo dos árcades.

PROFESSOR ETTORE ONORATO (cadeira de Mineralogia e Geologia) - Uma conferencia no dia 8 de setembro, sobre "Pedras preciosas".

PROFESSOR LUIGI FANTAPPIÉ (cadeira de Analyse Mathematica) - Uma conferencia, no dia 15 de setembro, sobre "O problema do ensino secundario de mathematica".

PROFESSOR ANDRE DREYFUS (cadeira de Biologia geral) Duas conferencias, nos dias 22 e 28 de setembro, sobre "Alguns aspectos dos problemas da sexualidade".

PROFESOR FERNAND PAUL BRAUDEL (cadeira de Historia da Civilização) - Tres conferencias, nos dias 2, 9 e 16 de setembro: $O$ fim de Napoleão; Anatole France e a Historia e $O$ nascimento da Europa.

PROFESSOR PLINIO AYROSA (cadeira de Ethnographia Brasileira e Lingua Tupy-Guarany) - Uma conferencia no dia 23 de outubro sobre "Adornos e insignias dos povos naturaes".

PROFESSOR PAUL ARBOUSSE-BASTIDE (cadeira de Sociologia) - Uma conferencia no dia 30 de outubro, sobre "O ensino secundario, chave de toda reforma educacional".

PROFESSOR JEAN MAUGUE (cadeira de Philosophia) - Conferencias da moral contemporanea, assim desdobradas: 0 problema da salvação; Grandeza e miseria do idealismo; A moral e a sciencia. 
PROFESSOR GLEB WATAGHin (cadeira de Physica geral e experimental) - Uma conferencia no dia 24 de outubro, sobre "O principio da casualidade em Physica moderna".

PROFESSOR DR. A. DE ALMEIDA PRADO (director da Faculdade de Philosophia, Sciencias e Letras) - Uma conferencia, encerrando a segunda serie de palestras da Faculdade, no dia 31 de outubro, sobre "As doenças através dos tempos".

EMBAIXADOR SALVADOR MADARIAGA - Em visita a esta Capital, realizou em 24 de agosto, no salão "João Mendes", interessante conferencia sobre a these "Origens psychologicas da crise mundial".

Apresentado pelo Reitor da Universidade de S. Paulo, que presidia á sessão, o illustre diplomata e ex-professor da Universidade de Oxford, discursou brilhantemente, tendo sido fartamente applaudido pela immensa assistencia, em que figuravam o dr. Cantidio Moura Campos, secretario da Educação, os representantes dos secretarios do Governo, o dr. Reynaldo Porchat, Reitor da Universidade, o dr. Francisco Morato, Director da Faculdade de Direito e grande numero de professores dos Institutos Universitarios.

LORD MAC MILLAN - Logo depois, a 27 de agosto, fez uma conferencia no mesmo amphitheatro, o notavel jurista e professor Lord Mac Millan, membro do Conselho Privado do Rei da Inglaterra, da Corte Suprema Ingleza, Presidente do Conselho da Universidade de Londres.

Versou sua oração sobre o suggestivo topico "Education for pleasure", agradando sobremaneira á selecta e immensa assistencia. Logo no começo do discurso, após o exordio, leu o conferencista uma delicada saudação que, pelo seu intermedio mandava a S. Paulo e aos paulistas, o Principe de Galles; gentileza real que o auditorio acolheu e louvou com vivo reconhecimento.

HAROLD BLUTER - Em 20 de dezembro seguinte, ainda no mesmo recinto, proferiu apreciada oração sobre o assumpto "Repartição Internacional do Trabalho", o sr. Haroldo Bluter, director da Repartição Intenacional do Trabalho, então nesta Capital, de passagem para Santiago do Chile.

o orador foi apresentado á assistencia pelo dr. José Carlos de Macedo Soares e recebeu geraes applausos pela sua palestra.

\section{EDIFICIO NOVO (*)}

Como se deparasse insufficiente para os serviços da Faculdade o edificio onde ella se alojava ha mais de um seculo, sobretudo de-

(*) Vide clichés em annexo. 
pois do augmento dos cursos, fizeram-se varios estudos de reforma e ampliação.

Como primeira tentativa, imaginou-se um anteprojecto de reforma do atrio de entrada e de construcção de um amphitheatro no pateo sobre a rua do Riachuelo.

No restante do edificio executar-se-iam reparações do telhado, dos tectos e pavimentos, bem como pintura geral.

Este plano, que conservava na sua totalidade o secular edificio, considerou-se um méro palliativo para rémediar a situação da Escola.

Um novo estudo foi feito com o intuito de conservar, do velho casarão apenas as duas peças que o espirito iconoclásta imaginava guardar a tradição, a saber, o pateo das arcadas e o pateo do mausoleu de Julio Frank. As demais dependencias seriam demolidas para dar logar a um edificio apropriado ao funccionamento da Academia.

O projecto foi orientado com o fim de distribuir, em torno das duas peças tradicionaes existentes e obrigatorias, as necessarias para o alojamento dos varios departamentos da Faculdade, de modo a se observarem suas relações mutuas, evidenciadas pelo schema funccional do edificio.

O edificio foi planejado em 4 pavimentos, nos quaes se localizariam os departamentos correspondentes ao corpo docente e discente, bibliotheca e administração, independentes e intercommunicantes.

Embasamento - Este pavimento, ao nivel superior da rua do Riachuelo, destina-se ás installações do Centro Academico XI de Agosto, á moradia do Zelador e ao deposito.

1. pavimento - Ao nivel do Largo de S. Francisco. A entrada principal, sob um Portico avançado em arcaria, conduz ao atrio de ingresso, do qual passa-se ao Hall de escada e elevadores e ao Pateo das Arcadas. Constituem estas tres as principaes peças de circulação do edificio. O conjuncto do pateo das arcadas, do hall e do pateo do mausoleu, orientado pelo mesmo eixo, lembrará pela sua architectura, na qual serão reproduzidas em sua forma primitiva as pilastras e os arcos do antigo claustro dos Franciscanos, o tradicional ambiente do pateo e as formas architectonicas da época de sua fundação.

São estas as unicas peças do edificio tratadas com decoração architectonica. O restante será cuidado com a simplicidade necessaria a uma escola moderna, onde deverão predominar as condições de hygiene, conforto e facil conservação.

Os corredores do claustro conduzem ás salas de aula ns. 1 a 5, com capacidade total para 970 alumnos, ás salas de descanço 
dos estudantes, á sala dos antigos alumnos, ás salas de Portaria e de Bedeis e aos gabinetes sanitarios.

2. pavimento - Destina-se principalmente á Congregação $o_{b} A d m i$. nistração e Bibliotheca.

No $10^{\circ}$ pavimento grupam-se as salas de Congregação, Bécas, Conselho Technico, duas salas de Recepção e as Tribunas da Congregação, no Grande Theatro Academico de 900 logares.

A Administração conta com a sala do Director, sala do Secretario, Secretaric e Thesouraria.

A Bibliotheca estão destinadas a sala de Leitura Geral, sala de Jornaes, salla do Bibliothecario, Museu Academico, sala de Livros, com capacidade actual para 50.000 e futura para 100.000 volumes, Estufa e Encadernação.

As installações sanitarias, bem como as de agua filtrada e esterilizada estão localizadas para servir a cada departamento.

3. Pavimento - Destina-se ás salas de aula ns. 1 a 5 , com capacidade total para 625 logares e 5 salas de provas escriplas, com capacidade total para 150 logares. Salla de archivo e sala de almoxarifado. Balcão do Theatro Academico com 341 logares.

Fachada: - A fachada obedece ao baroco em voga na época da fundação da Faculdade, tendo sido as portadas, balcões e molduras inspirados em motivos do Aleijadinho, encontrados nas obras deste artista brasileiro.

Com a creação da Universidade de S. Paulo, foi solicitado o augmento de um pavimento no projecto anterior, afim de nelle funccionar a Reitoria da Universidade. Com o complemento da fachada anterior, cuja parte posterior, á rua do Riachuelo já se achava construida, foi estudada uma nova fachada com um ultimo pavimento em attico. Constitue esta fachada, com as plantas já descriptas, o projecto definitivo do edificio.

Como variante do frontespicio acima mencionado, foi solicitado um estudo de fachada com torre universitaria de grande altura, para dominar no centro dos futuros edificios da praça, estudo que a Congregação rejeitou em sessão realizada em setembro, approvando unanimemente o projecto sem torre, elaborado pelos architectos Severo \& Villares.

\section{OBRAS REALIZADAS EM 1935}

Demolição do edificio velho na segunda phase: Inicio - na primeira semana de fevereiro. Terminação — fim de abril.

Achados - Nas paredes da sala $n^{\circ}$. 1 foram encontradas 4 carneiras, contendo ossadas, das quaes tomou conta a Policia Technica. 
Sobre as mesmas, o Gabinete de Investigações fez varias pesquizas, cujos resultados se publicaram no "O Estado de S. Paulo", de 28 de junho.

Construcção - Terminação da primeira phase - Proseguiram os trabalhos de revestimento e decoração das fachadas da parte construida na primeira phase das obras, onde está funccionando a Faculdade.

2." phase: - Iniciaram-se os serviços de construcção da 2." parte projectada, que consiste no restante do prédio, com excepção do grande amphitheatro.

Obras realizadas: - Fundações - Após as experiencias do terreno, foram abertos poços de fundação, a começar da divisa com a rua Christovam Colombo. A primeira fundação foi concretada em 17 de setembro. Até 31 de deżembro foram concluidas as seguintes peças de armadura de concreto armado: Fundações -80 sapatas, faltando 6 que dependem da autorização dos visinhos do Convento de S. Francisco. Columnas: 46 até o nivel da 1." lage. Lages: a 1." lage da ala direita e do corpo central na parte da frente. Total de metras cubicos de concreto: Fundaçõets: 390; Columnas, 75, Vigas e Lages, 119.

PROJECTO - A Congregação, em ultima decisão, approvou, na presença do engenheiro dr. Alfredo Máthias, representante da Directoria de Obras Publicas da Secretaria da Viação junto ás obras da Faculdade, o projecto definitivo do edificio, do qual descrevemos as plantas e fachada.

CUSTO DA EDIFICAÇÃO ATE O FIM DO ANNO. - As despesas com as obras da nova construcção, até 31 de dezembro de 1935, importam precisamente em dois mil cento e seis contos tresentos e quarenta e tres mil quatrocentos e setenta e cinco réis $(2.106: 343 \$ 475)$.

\section{A BIBLIOTHECA}

Era aqui particularmente que os serviços se manifestavam chaoticos e em completa desordem, devido á deficiencia de pessoal, á mudança de livros para a nova installação e a um pouco de invigilancia nas execuções de ordem technica.

Aguardavam classificação, recortes, selecção de artigos de doutrina e fichagem centenas de obras, milhares de jornaes, immensos fasciculos e volumes de revistas e publicações diversas. Os catalogos achavam-se atrazadissimos, os livros empilhados aqui ou alli; sem disposição de materia ou sequencia de tal arte a fazer perder a paciencia aos consulentes, frustrar a procura e inutilizar os catalogos alphabeticos; muitas obras desapparecidas ou truncadas; 
interrompidas as assignaturas de revistas e publicações periodicas; pó e falta de limpeza por toda a parte.

Urgia atacar resolutamente a fichagem em atrazo, a revisão, reclassificação e tabellamento das fichas abandonadas, a revisão do indice alphabetico, o renovamento dos catalogos onomastico e methodico, a classificação e fichagem dos volumes que entram diariamente e dos que por centenas jazem postos de lado, a limpeza das estantes, a arrumação e tratamento dos livros, e outros serviços que taes.

Para isso conseguimos augmentar o pessoal, fortalecer as verbas de custeio e quasi duplicar o trabalho, creando o serviço da noite ao lado do serviço do dia.

Parallelamente, desejando dar maior divulgação, efficiencia e utilidade á bibliotheca, inauguramos o periodo nocturno de consultas e o serviço de publicidade semanal, por meio da imprensa e das estações radiodiffusoras.

As consultas ascenderam ao total de 30.980 contra 16.240 em 1934, o que implica um augmento de 14.740 .

Outrosim, para permittir aos nossos consulentes e aos estudantes de direito andarem ao facto do que de mais importante se pensa dia a dia no mundo, maximé no circulo do movimento intellectual, fizemos tomar a assignatura de algumas revistas literarias e jornaes argentinos, francezes, italianos, inglezes e americanos, além das publicações nacionaes e revistas de jurisprudencia. Cremos que o nosso salão de leitura ha-de tornar-se um dos mais attrahentes da Capital.

Com seu novo apparelhamento e organização, sob a intelligente chefia technica do sr. Antonio Constantino e expediente a cargo do encarregado sr. Agilulpho Candido Dias, um e outro funccionarios habeis e devotados, esperamos que tudo estará normalizado antes de acabado o anno.

Ao pôr termo a este relatorio, cumpre-nos registrar, Exmo. sr., que temos tido todo o apoio, prestigio, boa vontade e facilidade da parte do Governo de V. Excia., para desempenho de nossos deveres, tanto no que diz respeito á reconstrucção do edificio da Faculdade quanto no que toca ao seu movimento administrativo e escolar, já em relação aos dispendios extraordinarios com as novas obras, já em relação ao custeamento normal da academia.

A solicitude com que tem acudido aos nossos appellos e o zelo que da causa do ensino tem demonstrado o dr. Cantidio de Moura Campos, secretario da Educação, hão-de consagral-o um dos mais insignes benemeritos da Faculdade de São Paulo.

Francisco morato.

São Paulo, $31-1-1936$. 


\section{RELATORIO DA SECRETARIA}

\section{DIRECTORIA}

Exerceram a Directoria durante o anno de 1935:

- de 1 a 24 de janeiro, o prof. Dr. Waldemar Martins Ferreira, como Vice-Director eleito pelo Conselho Technico-Administrativo, que renunciou ao cargo á vista do disposto no art. 33 da Constituição da Republica, por ter sido diplomado deputado federal;

- de 25 de janeiro a 10 de fevereiro, o prof. Dr. Candido N. Nogueira da Motta, eleito pelo Conselho Technico-Adimnistrativo, que deixou o cargo por motivo de molestia;

- de 11 de fevereiro a 25 de abril, o prof. Dr. Raphael Corrêa de Sampaio, que deixou o cargo por necessitar ausentar-se da Capital;

- de 26 de abril a 15 de maio, novamente o prof. Dr. Candido N. Nogueira da Motta, eleito pelo Conselho Technico-Administrativo.

- de 16 de maio a 31 de dezembro, o prof. Dr. Francisco Morato, nomeado por decreto de 14 de maio do Governo Estadual.

\section{VICE-DIRECTORIA}

O prof. Dr. Raphael Corrêa de Sampaio foi eleito, de accôrdo com o art. 21 do Regulamento, pelo Conselho Technico-Administrativo, em sessão realizada a 21 de agosto, para exercer o cargo de Vice-Director.

\section{CONSELHO TECHNIICO-ADMINISTRATIVO}

Para membros deste Conselho foram nomeados pelo Snr. Secretario da Educação:

- o prof. Dr. Jorge Americano (acto de 14 de maio - exercicio a 20 deste mez);

- o prof. dr. Honorio Fernandes Monteiro (acto de 14 de maio

- exercicio a 20 deste mez);

- o prof. Dr. Antonio de Sampaio Doria (acto de 8 de agosto exercicio a 21 deste mez); e

— o prof. Dr. Mario Masagão (acto de 8 de agosto - exercicio a 21 deste mez).

Além desses professores, fazem, ainda, parte do Conselho, os Drs. Raphael Corrêa de Sampaio e Gabriel José Rodrigues de Rezende Filho.

O Conselho realizou, durante o anno, 16 sessões. 

guintes :

Entre as deliberações tomadas pelo Conselho, relevam-se as se-

- tomar conhecimento do orçamento da Faculdade, composto de duas partes distinctas, uma a cargo do Governo Federal e outra a cargo do Governador do Estado, approvando-as (sessão de 23 de janeiro);

- fixar a 2." quinzena de fevereiro e a $1 .^{2}$ de março, respectivamente, para a inscripção e exames de 2." época do Curso de Bachatrelado, em virtude do disposto no ant. $3 .^{\circ}$ da Lei n..$^{\circ}$-A, de 12-12-34 (sessão de 23 de janeiro);

- fixar em 260 o numero de matriculas no $10^{\circ}$ anno do Curso de Bacharelado, ficando, nos demais annos, as respectivas matriculas limitadas aos alumnos approvados ou promovidos nos annos anteriores (sessão de 23 de janeiro);

- não acceittar transferencias de estudantes de outras Faculdades, no corrente anno lectivo, devido ao grande numero de alumnos promovidos e á deficiencia das installações da Faculdade, em virtude da demolição de parte do predio (sessão de 23 de janeiro);

- admittir a promoção, em 2." época, dos alumnos do Curso de Bacharelado que obtiverem a media e frequencia necessarias e não tenham requerido a promoção em 1." época (sessão de 23 de janeiro);

- approvar a indicação do Snr. Bernardo Stonoga para o cargo de ascensoristia da Faculdade (sessão de 16 de fevereiro);

- indeferir a inscripção dos bachareis Raul Renato Cardoso de Mello Tucunduva e Benedicto Siqueira Ferreira ao concurso de professor cathedratico de Direito Judiciario Civil, por não terem os mesmos preenchido varios requisitos legaes (sessão de 6 de março);

28 de março);

- approvar o horario para o Curso de Bacharelado (sessão de

- determinar que as aulas sejam iniciadas em 8 de abril, devido aos exames de 2." época, que se realizaram em março, em consequencia do disposto no art. $3 .^{\circ}$ da Lei n. ${ }^{\circ}$ 9-A, de 12-12-34 (seissão de $10^{\circ}$ de abril);

- consignar em acta um voto de louvor e agradecimento ao prof. Dr. Waldemar Martins Ferreira, quando da sua renuncia de membro deste Conselho e afastamento de sua cathedra, em virtude de haver sido diplomado deputado federal (sessão de 22 de abril);

- approvar a seguinte proposta de promoção de funccionarios, apresentada pelo Exmo. Snr. Dr. Director, em virtude da promoção a secretario do auxiliar de secretario: para auxiliar de secretario (chefe de secção), o chefe de secção Raul de Assumpção Sampaio; para chefe de secção, o 1.0 escripturario bacharel Julio de Barros; para $10^{\circ}$ escripturario, o $2 .^{\circ}$ Frederico Baptista de Sousa; para 2..$^{\circ}$ es- 
cripturario, o $3 .^{\circ}$ Geraldo da Silva Leite; para $3 .^{\circ}$ escripturario, o $4 .^{\circ}$ Adolpho Schmidt Junior; para $4 .^{\circ}$ escripturario, o bedel José Martinho de Moura Baptista; para bedel effectivo, o bedel interino Jeronymo Teixeira da Silva; para bedel interino, o servente Luis Gonzaga Nazareth e para servente o sr. Manoel Ribeiro de Almeida (sessão de 23 de abril);

- consignar em acta a satisfação do Conselho por ver confirmado no cargo, em que tem prestado tantos e bons serviços, o secretario Snr. Flavio Mendes (sessão de 22 de abril);

- transcrever em acta, a seguinte carta do prof. Dr. Alcantara Machado:

"São Paulo, 16 de maio de 1935. - Exmo. Sr. Director da Faculdade de Direito.

Exonerado, por decreto de ôntem, do cargo de Diretor desse instituto, que exerci durante cerca de quatro annos, venho pedir a V. Exa. a gentileza de significar a minha gratidão áqueles dentre os professores e os funccionarios administrativos, que me prestaram o seu concurso inestimavel para o desempenho de meus deveres. Manda-me a justiça mencionar com especial carinho os professores Candido Motta, Raphael Sampaio, Gama Cerqueira, Cardoso de Mello Neto, Sampaio Doria e Spencer Vampré, que comigo serviram no Conselho Tecnico e Administrativo; o professor Honorio Monteiro, que tanto me auxiliou na organização da contadoria e reorganização da Tesouraria; os srs. Sergio Milliet da Costa e Silva, Flavio Mendes e Cassio José de Toledo collaboradores dedicados, competentes e leais da obra, que levei a efeito. Deixando aqui as minhas despedidas a V. Exa., aos professores acima nomeados e ainda aos professores Mario Masagão, Souza Carvalho, Jorge Americano, Ernesto Leme, Soares de Faria, Almeida Junior, Lino Leme, José Augusto Ciesar, Gabriel de Rezende Filho, Pinto Ferreira, Waldemar Ferreira, Noé Azevedo e Francisco Morato, - faço votos para que, sob a direcção de V. Exa., a Faculdade continue a honrar a cultura nacional. Do col. e admor. (a.) Alcantara Machado" (sessão de 20 de maio);

- approvar a indicação do Snr. Francisco Emygdio Pereira Neto para exercer, interinamente, o cargo de $4 .^{\circ}$ elscripturario desta Faculdade (sessão de 20 de maio);

- approvar a deliberação do Exmo. Sr. Dr. Director de nomear alguns serventes e solicitar do Governo autorização para contractar tres dactylographos (sessão de 26 de julho);

- approvar a proposta orçamentaria para 1936 (sessão de 21 de agosto);

- encaminhar ao poder competente uma proposta para augmento de vencimentos do secretario, thesoureiro, porteiro, encadernadores e ascensorista (sessão de 21 de agosto); 
- autorizar o Exmo. Snr. Dr. Director a propor ao Governo o. contracto de D. Maria José do Amaral Santos para dactylographa, e a criação de mais dois cargos de bedel, cuja despesa foi incluida na proposta orçamentaria para 1936 (sessão de 21 de agosto);

- approvar os programmas para os exames vestibulares de 1936 e para o exame de selecção do Collegio Universitario, a que se refere o art. 40 do respectivo Regulamento, determinando, outrosim, a sua publicação (sessão de 12 de setembro);

— iniciar os exames de 1." época no dia 3 de dezembro (sessão de 29 de novembro) .

\section{CONGREGAÇ.̃̃O}

A Congregação reuniu-se nos dias $10^{\circ}$ de fevereiro, 9 de março, 29 de abril, 6 de agosto, 12 de setembro, 1, 4, 22, 24, 28, 30 e 31 de outubro, 5, 7, 9, 11, 13, 19 e 22 de novembro, e 9 de dezembro.

Entre as deliberações tomadas pela Congregação, relevam-se as se'guintes :

- applicar a seriação do actual regulamento sómente ao $1 .^{\circ}$ anno do Curso de Bacharelado, mantendo para os demais annos do curso a seriação anterior, isto é, a constante do decreto federal n..$^{\circ}$ 19.852, de 11 de abril de 1931, evitando, assim, os inconvenientes de uma nova mudança de regimen didactico (sessão de $10^{\circ}$ de fevereiro);

- eleger os profs. Drs. Mario Masagão, Honorio Fernandes Monteiro e Alexandre Correia para a commissão de redacção da Revista da Faculdade (sessão de 9 de março);

- eleger o prof. Dr. Jorge Americano para supplente do representante da Congregação, prof. Raphael Corrêa de Sampaio, junto ao Conselho Universitario (sessão de 9 de março);

- declarar-se contraria á transferencia da Faculdade para o local que fosse escolhido para a futura Cidade Universitaria (sessão de 6 de agosto);

- fixar as materias Portuguez, Latim e Historia da Civilização para o exame de selecção do que trata o art. $40, \S 1 . \%$, do decreto estadual n. 6.829 , de 30 de novembro de 1934 (sessão de 6 de agosto);

- eleger as seguintes commissões examinadoras para a defesa de these dos alumnos que concluiram o Curso de Doutorado em 1932 (sessão de 12 de setembro):

Philosophia do Direito: - Profs. Drs. Alexandre Correia, Sebastião Soares de Faria e Noé Azevedo; 
Direito Commercial e Direito Civil Comparado: - Profs. Drs. Jorge Americano, Honorio Monteiro e Ernesto Leme;

Direito Publico: - Profs. Drs. Francisco Morato, A. de Sampaio Doria e M. F. Pinto Pereira;

Criminologia: - Profs. Drs. Raphael Sampaio, Gabriel de Rezende Filho e Noé Azevedo;

Direito Internacional Privado: - Profs. Drs. T. B. de Sousa Carvalho, Braz de Sousa Arruda e Lino Leme;

- eleger as seguintes commissões examinadoras para os concursos á livre docencia (sessão de $10^{\circ}$ de outubro);

Economia Politica e Sciencia das Finanças: - Profs. Drs. Raphael Corrêa de Sampaio, Mario Masagão, Gabriel de Rezende Filho, Honorio Monteiro e Alexandre Correia;

Direito Publico Constitucional: - Profs. Drs. Francisco Morato, Antonio de Sampaio Doria, Gabriel de Rezende Filho, Jorge Americano e Ernesto Leme;

Direito Internacional Publico: - Profs. Drs. Raphael Corrêa de Sampaio, T. B. de Sousa Carvalho, Francisco Morato, Braz de Sousa Arruda e A. de Sampaio Doria;

Introducçâo á Sciencia do Direito: - Profs. Drs. Mario Masagão, Jorge Americano, Ernesto Leme, Honorio Monteiro e Alexandre Correia; e

Historia do Direito Nacional: - Profs. Drs. T. B. de Sousa Carvalho (substituido, por motivo de luto, pelo Prof. Dr. Honorio Monteiro), Francisco Morato, Braz de Sousa Arruda, Gabriel de Rezende Filho e Alexandre Correia;

- fixar o primeiro dia util da 2." quinzena de março de 1936 para a defesa de these dos alumnos que concluiram o Curso de Doutorado (sessão de 19 de novembro);

- supprimir o Curso de Doutorado, conforme lhe faculton a lei federal n. 114 , de 11 de novembro de 1935 (sessão de 22 de novembro);

- encaminhar á Assembléa Legislativa Estadual a seguinte representação (sessão de 22 de novembro):

"Tendo votado a suppressão do curso de doutorado, de conformidade com a lei federal $n .^{\circ} 114$, de 11 do corrente, - vem a Congregação da Faculdade de Direito da Universidade de São Paulo suggerir á honrada Assembléa Legislativa do Estado as providencias relativas ao curso de bacharelado, constantes do projecto abaixo, onde, sem augmento de despezas, e antes com reducção delas, ficam attendidas as determinações daquella lei federal, e outras exigencias prementes do curso juridico.

Art. $10^{\circ}$ - Ficam transferidas do curso de doutorado para o curso de bacharelado da Faculdade de Direito da Universidade de 
São Paulo as cadeiras de Direito Publico (Theoria Geral do Estado), Sciencia das Finanças, Direito Internacional Publico e Philosophia do Direito.

Art. 2.0 - O Curso de bacharelado passa a ser feito em seis annos, obedecida a seguinte seriação:

1. Anno: - 1.a cadeira - Introducção á Sciencia do Direito (aulas diarias)

2." cadeira - Direito Romano

3." cadeira - Economia Politica

2. Anno: - 1..$^{\mathrm{a}}$ cadeira - Direito Civil (Parte geral e Theoria geral das Obrigações)

2." cadeira - Direito Penal (Parte Geral)

3. ${ }^{2}$ cadeira - Direito Publico (Theoria Geral do Estado)

4. ${ }^{a}$ cadeira - Sciencia das Finanças

3. Anno: - 1..$^{\mathrm{a}}$ cadeira - Direito Civil (Obrigações e contractos em especie)

2.a cadeira - Direito Penal (Crimes em especie e regime penitenciario)

3." cadeira - Direito Commercial (1." parte)

4." cadeira — Direito Constitucional

4. Anno: - 1." cadeira - Direito Civil (Direito das Coisas)

2." cadeira - Medicina Legal

3." cadeira - Direito Commercial (2.* parte)

4." cadeira - Direito Judiciario Civil

5. Anno: - 1..$^{\mathrm{a}}$ cadeira - Direito Civil (Familia e Successões)

2. ${ }^{\mathrm{a}}$ cadeira - Direito Commercial e Dir. Maritimo

3." cadeira — Direito Judiciario Civil

4." cadeira - Direito Administrativo e Sciencia da Administração

6. Anno: - 1.. cadeira - Direito Judiciario Civil

2." cadeira - Direito Judiciario Penal

3. ${ }^{a}$ cadeira - Direito Internacional Publico

4." cadeira - Direito Internacional Privado

5." cadeira - Philosophia do Direito.

Art. 3. - A seriação acima estatuida applicar-se-á ao $10^{\circ}$ anno do curso em 1936, ao $10^{\circ}$ e ao $20^{\circ}$ em 1937 , e assim successivamente.

Art. $40^{\circ}$ - E' limitada ao numero maximo de 200 alumnos a matricula no $10^{\circ}$ anno do curso de bacharelado, não podendo cada turma ter mais de cem alumnos. 
Art. 5. - 0 Conselho Technico da Faculdade de Direito não concederá transferencia de alumnos de outras escolas para série na qual haja, matriculados ou com direito á matricula, estudantes em numero superior a cem.

Art. $60^{\circ}$ - Poder-se-á obter gráo de doutor em direito, mediante defeza de theses, na forma que fôr determinada no Regimento Interno da Faculdade.

Art. 7. - Ficam restabelecidas as taxas constantes da tabela annexa ao decreto $n .^{\circ} 6.429$, de 9 de maio de 1934 .

- Incluir no Curso de Bacharelando, a cadeira de Criminologia, que será cursada no $4 .^{\circ}$ anno (sessão de 22 de novembro).

\section{CORPO DOCENTE}

Na 1." sessão da Congregação, realizada em $10^{\circ}$ de Fevereiro, verificou-se que se achavam promptos para desempenhar as suas funcções durante o anno, os Snrs. Professores Cathedraticos, Drs. Candido N. Nogueira da Motta, Raphael Corrêa de Sampaio, Theophilo Benedicto de Sousa Carvalho, Spencer Vampré, Francisco Morato, Braz de Sousa Arruda, Antonio de Sampaio Doria, Waldemar Ferreira, Mario Masagão, Gabriel de Rezende Filho, Jorge Americano, Ernesto de Moraes Leme, Honorio Fernandes Monteiro, Alexandre Correia, José Augusto Cesar, e os docentes livres Drs. Antonio Ferreira de Almeida Junior, Manoel Francisco Pinto Pereira, Noé Azevedo e Sebastião Soares de Faria.

Não compareceram os Profs. Cathedraticos, Drs. José de Alcantara Machado d'Oliveira e J. J. Ciardoso de Mello Neto, por se acharem com assento no Senado Federal e Camara dos Deputados, respectivamente; Dr. Vicente Ráo, por se achar no exercicio do cargo de Ministro da Justiça e Dr. Luiz Barbosa da Gama Cerqueira, por se achar commissionado junto ao Ministerio da Justiça.

Na mesma sessão, o Dr. Ernesto de Moraes Leme declarou que o livre docente Dr. Lino Leme estava prompto para o serviço da Faculdade, no correr desse anno.

\section{1 - Commissionamentos}

1 - O prof. Luiz Barbosa da Gama Cerqueira esteve em Commissão junto ao Ministerio da Justiça, de $10^{\circ}$ de Janeiro a 30 de Abril.

2 - o prof. Antonio de Sampaio Doria esteve em commissão junto ao Ministerio da Justiça de $10^{\circ}$ de Janeiro a 18 de Março. 
3 - 0 prof. Spencer Vampré esteve em commissão junto ao Ministerio da Educação, de 15 de Junho a 31 de Dezembro.

4 - 0 prof. Ernesto de Moraes Leme que deixara o exercicio do seu cargo em 30 de março, por ter sido diplomado deputado á Constituinte Estadual, reassumiu o exercicio no dia 31 de agosto, após as aulas, nos termos do art. $13, \S 4 .^{\circ}$ da Constituição do Estado.

\section{2 - Aposentadorias}

0 prof. Candido N. Nogueira da Motta requereu, em 15 de julho, ao Snr. Ministro da Educação, a sua aposentadoria, que ainda não foi decretada, tendo deixado, naquella data, o exercicio do seu cargo.

\section{3 - Licenças}

O prof. Candido N. Nogueira da Motta esteve no gozo de licença, de 28 de março a 25 de abril.

0 prof. Spencer Vampré esteve no gozo de licença, de 26 de abril a 25 de maio.

\section{4 - Substituições}

0 prof. Candido Motta substituiu, de $10^{\circ}$ de janeiro a 27 de março, e de 21 de maio a 15 de julho, ao prof. Luiz Barbosa da Gama Cerqueira, na regencia da cadeira de Criminologia do $1 .^{\circ}$ anno do Curso de Doutorado.

O prof. T. B. de Sousa Carvalho substituiu, de 1 de julho a 31 de dezembro, ao prof. Waldemar Martins Ferreira, na regencia da cadeira de Historia do Direito Nacional, do $10^{\circ}$ anno do Curso de Doutorado.

0 prof. Spencer Vampré substituiu, de $10^{\circ}$ de janeiro a 18 de março, ao prof. A. de Sampaio Doria, na regencia da cadeira de Direito Constitucional, do $2 .^{\circ}$ anno do Curso de Bacharelado.

O prof. Braz de Sousa Arruda substituiu ao prof. L. B. da Gama Cerqueira, de 23 a 31 de maio, na regencia da cadeira de Direito Penal, do 3.० anno do Curso de Bacharelando; ao prof. J. J. Cardoso de Mello Neto, de $10^{\circ}$ de janeiro a 31 de dezembro, na regencia da cadeira de Sciencia das Finanças, do $20^{\circ}$ anno do Curso de Doutorado; ao prof. Vicente Ráo, de $10^{\circ}$ de Janeiro a 31 de julho, na regencia da cadeira de Direito Publico, do $10^{\circ}$ anno do Curso de Doutorado; de $10^{\circ}$ de agosto a 31 de dezembro, regeu a cadeira vaga de Direito Civil Comparado, do $11^{\circ}$ anno do Curso de Doutorado; 
O prof. Antonio de Sampaio Doria substituiu ao prof. Vicente Ráo, de $10^{\circ}$ de agosto a 31 de dezembro, na regencia da cadeira de Direito Publico, do $10^{\circ}$ anno do Curso de Doutorado;

0 prof. Mario Masagão substituiu, de 26 de abril a 31 de agosto, ao prof. J. J. Cardoso de Mello Neto, na regencia da cadeira de Economia Politica e Sciencia das Finanças, do $10^{\circ}$ anno do Curso de Bacharelado; regeu tambem, de $10^{\circ}$ de janeiro a 28 de fevereiro, a cadeira vaga de Philosophia do Direito, do $2 .^{\circ}$ anno do Curso de Doutorado;

O prof. Gabriel de Rezende Filho substituiu ao prof. L. B. da Gama Cerqueira, de $10^{\circ}$ de junho a 17 de julho, na regencia da cadeira de Dirito Penal, do $3 .^{\circ}$ anno, do Curso de Bacharelado;

0 prof. Jorge Americano substituiu, de $10^{\circ}$ de janeiro a 31 de dezembro, ao prof. Vicente Ráo, na regencia da cadeira de Direito Civil, do 3..$^{\circ}$ anno do Curso de Bacharelado;

0 prof. Honorio Fernandes Monteiro regeu, de $10^{\circ}$ de março a 31 de dezembro, a cadeira vaga de Direito Civil, do $40^{\circ}$ anno do Curso de Bacharelado; substituiu ao prof. A. de Sampaio Doria, de $10^{\circ}$ de janeiro a 18 de março, na regencia da cadeira de Economia e Legislação Social, do $10^{\circ}$ anno do Curso de Doutorado; substituiu ao prof. Waldemar Martins Ferreira, de 23 de abril a 31 de dezembro, na regencia da cadeira de Direito Commercial, do $4 .^{\circ}$ anno do Curso de Bacharelado.

$O$ prof. Alexandre Correia regeu, de $10^{\circ}$ de março a 31 de dezembro, a cadeira vaga de Philosophia do Direito, do $2 .^{\circ}$ anno do Curso de Doutorado;

O livre docente, prof. A. F. de Almeida Junior substituiu, de 1. de janeiro a 31 de dezembro, ao prof. José de Alcantara Machado d'Oliveira, na regencia da cadeira de Medicina Legal, do $4 .^{\circ}$ anno do Curso de Bacharelado;

0 livre docente, prof. Lino de Moraes Leme regeu, de $10^{\circ}$ de abril a 31 de dezembro, a cadeira vaga de Direito Civil, do $2 .^{\circ}$ anno do Curso de Bacharelado;

O livre docente, prof. Noé Azevedo substituiu, de 28 de março a 25 de abril, de $10^{\circ}$ a 21 de junho e de 18 de julho a 31 de dezembro, ao prof. Candido Motta, na regencia da cadeira de Direito Penal, do $2 .^{\circ}$ anno do Curso de Bacharelado; e ao prof. Luiz Barbosa da Gama Cerqueira, na regencia da cadeira de Direito Penal, de $10^{\circ}$ de janeiro a 22 de maio e de 18 de julho a 31 de dezembro;

0 livre docente, prof. M. F. Pinto Ferreira substituiu, de $1 .^{\circ}$ de janeiro a 25 de abril, ao prof. J. J. Cardoso de Mello Neto, na regencia da cadeira de Economia Politica e Sciencia da Finanças, do 1. anno do Curso de Bacharelado, e de 26 de abril a 31 de dezem- 
bro, ao prof. Spencer Vampré, na regencia da cadeira de Introducção á Sciencia do Direito, tambem do $10^{\circ}$ anno do Curso de Bacharelado;

O livre docente, prof. Sebastião Soares de Faria substituiu, de 1 de abril a 31 de agosto, nao prof. Ernesto de Moraes Leme, na regencia da cadeira de Direito Commercial, do $3 .^{\circ}$ anno do curso de Bacharelado, e de $10^{\circ}$ de setembro a 31 de dezembro, ao prof. J. J. Cardoso de Mello Neto, na regencia da cadeira de Economia Politica e Sciencia das Finanças, do $10^{\circ}$ anno do Curso de Bacharelado.

\section{5 - Designação de Professor Substituto}

O desembargador dr. Manuel Carlos de Figueiredo Ferraz foi designado, em portaria de 24 de agosto, do Director da Faculdade, para substituir ao prof. Luiz Barbosa da Gama Cerqueira, a partir de 8 do mesmo mez, na regencia da cadeira de Criminologia, do $10^{\circ}$ anno do Curso de Doutorado, de accordo com o art. 22, letra $c$, do decreto n. $^{\circ} 7.068$, de abril de 1935 , no exercicio da qual se manteve até 31 de dezembro.

\section{6 - Aulas Desdobradas}

Para maior efficiencia do ensino, foram desdobradas as aulas de todos os annos do Curso de Bacharelado, encarregando-se da sua regencia os respectivos cathedraticos, e, na falta destes, os substitutos designados.

\section{CONCURSO PARA PROFESSOR CATHEDRATICO DE DIREITO JUDIGIARIO CIVIL}

A' inscripção para o concurso de professor cathedratico de Direito Judiciario Civil (cadeira nova), encerrada em 6 de março, concorreram os bachareis Raul Renato Cardoso de Mello Tucunduva e Benedicto de Siqueira Ferreira.

O Conselho Technico-Administrativo, em sessão realizada naquelle mesmo dia, tomando conhecimento daquellas inscripções, resolveu indeferir ambos os pedidos, visto terem os candidatos deixado de prehencher os requisitos de folha corrida, pois não apresentaram certidões relativas ao Juizo Federal, Justiça Criminal, Justiça Eleitoral e Policia do Estado.

$\mathrm{Na}$ forma do $\S 4 .^{\circ}$ do art. 70 do regulamento então em vigor, recorreram os candidatos para a Congregação. Esta, em sessão 
realizada a 9 de março, negou provimento aos recursos, unanimemente, determinando que se abrisse, opportunamente, nova inscripção para o referido concurso.

\section{CONCURSO PARA PROFESSOR GATHEDRATICO DE PHILOSOPHIA DO DIREITO}

0 prof Dr. Alexandre Correia, unico candidato inscripto neste concurso, desistiu da sua inscripção, em requerimento despachado pelo Exmo. Snr. Dr. Director, em 11 de setembro.

\section{CONGURSOS A' LIVRE DOCENCIA}

Inscreveram-se para concurso á livre docencia, de conformidade com os arts. 78 e 79 do Regulamento em vigor, oito candidatos, a saber, um para Direito Publico Constitucional; um para Direito Publico Internacional; dois para Economia Politica; um para Historia do Direito Nacional, do Curso de Doutorado; dois para Introducção á Sciencia do Direito.

A Congregação da Faculdade reuniu-se em sessão especial, no dia 1. de outubro, para tomar conhecimento dos requerimentos de inscripção apresentados pelos respectivos candidatos, tendo deliberado admittir, feita a prova de residencia no Estado ba 10 annos como exige a Constituição Estadoal, todos os pedidos, por terem os mesmos preenchido todas as formalidades legaes, com excepção do que apresentou o bacharel Ruben Mariano da Rocha, por não ter este candidato exhibido, o exigido relativamente á folha corrida, certidões da Justiça Federal, Tribunal Eleitoral, Policia e attestados de actividade profissional relacionada com a disciplina em concurso.

Os trabalhos relativos ao concurso iniciaram-se no dia 18 de outubro e terminaram a 19 de novembro, não tendo nenhum dos candidatos logrado obter classificação.

Durante a realização das provas, o candidato Decio Ferraz Alvim apresentou requerimento de desistencia.

\section{CORPO DISCEN'TE}

\section{1 - Exames vestibulares}

De 2 a 22 de fevereiro realizaram-se os exames vestibulares. A commissão examinadora foi a seguinte: Prof. Drs. Raphael 
Corrêa de Sampaio (Literatura); Spencer Vampré (Latim); Mario Masagão (Psychologia e Logica); Gabriel de Rezende Filho (Geographia) e Honorio Monteiro (Hygiene).

0 resultado desses exames foi o seguinte:

Inscripção regular (16 a 31 de janeiro):

Exames de 2 a 21 de fevereiro:

Inscriptos

Approvados . . . . . . . . . . . . . . . . 133

Reprovados . . . . . . . . . . . . 179

Desistiram da oral . . . . . . . . . . . . . $\quad 3$

Não compareceram á oral . . . . . . . . . . . . $\quad \begin{array}{llll} & 5 & 320\end{array}$

Inscripção condicional (4 a 9 de fevereiro) - autorizada pelo Ministro da Educação, em telegramma de 29 de janeiro.

Exames de 19 a 22 de fevereiro: -

Inscriptos

Approvados . . . . . . . . . . . . . . .

Reprovados . . . . . . . . . . . . . 26

Desistiu da oral ... . . . . . . . . . . . 1

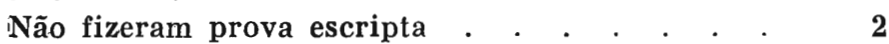

Resumo geral (Inscripções regulares e condicionaes)

Inscriptos

Approvados . . . . . . . . . . . . 141

Reprovados . . . . . . . . . . . . 205

Desistiram da prova oral . . . . . . . . . 4

Não compareceram á prova oral . . . . . . . . 5

Não fizeram prova escripta . . . . . . . . . 2

\section{2 - Curso de Bacharelado}

Matricularam-se neste curso 1.418 alumnos, dos quaes:

no $10^{\circ}$ anno . . . . . . . . . . . . . . . 341

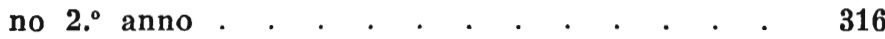

no $3 .^{\circ}$ anno . . . . . . . . . . . . . . . . . 237

no $40^{\circ}$ anno . . . . . . . . . . . . . . . . 298

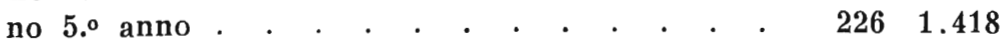

De 9 de março a 3 de abril realizaram-se os exames de segunda epoca.

As commissões examinadoras foram as seguintes: 
1. anno: - Profs. Drs. Raphael Sampaio, Mario Masagão e M. F. Pinto Pereira;

2. anno: - Profs. Drs. Spencer Vampré, Jorge Americano e Noé Azevedo;

3.' anno: - Profs. Drs. Waldemar Martins Ferreira, Jorge Americano e Noé Azevedo, tendo, tambem, havido uma commissão constituida pelos Profs. Drs. Ernesto Leme, Noé Azevedo e M. F. Pinto Pereira (exame de 3-4-35);

4. anno: - Profs. Drs. Gabriel de Rezende Filho, Jorge Americano, Ernesto Leme e A. Almeida Junior, tendo tambem o Prof. Dr. Raphael Sampaio funccionado em duas bancas (14/3/35 e 2/4/35) e o Prof. Dr. Mario Masagão em uma (14/3/35).

0 resultado foi o seguinte:

\section{ANNO}

Inscriptos 164

Promovidos . . . . . . .

Introdução

Approvados 0.68

Reprovados . $\quad . \quad . \quad . \quad . \quad . \quad .58$

Desistiram da oral . . . . . $\quad 1$

Já fizeram esta cadeira . . . $\quad 34$

Não compareceram á oral . . 1

164

\begin{tabular}{c} 
Economia \\
3 \\
67 \\
38 \\
-53 \\
3 \\
\hline 164
\end{tabular}

\section{2. $\quad$ ANNO}

Inscriptos 85

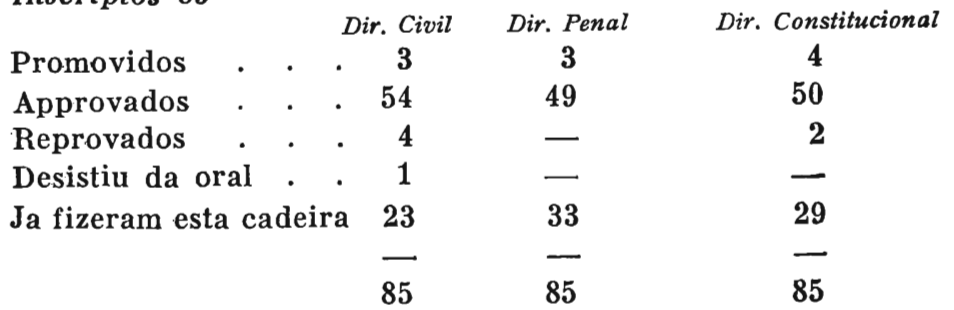

Incriptos 189

\section{3. $\quad$ ANNO}

\begin{tabular}{|c|c|c|c|c|}
\hline & & Dir. Civil & Dir. Penal & Dir. Commercial \\
\hline Promovidos & . & . 11 & 6 & 1 \\
\hline Distincção & . & 1 & 1 & - \\
\hline Approvados & . . & 40 & 77 & 116 \\
\hline
\end{tabular}




\begin{tabular}{|c|c|c|c|}
\hline Reprovados & Dir. Civil & Dir. Penal & Dir. Commercia \\
\hline Reprovados • • . & 17 & 1 & 45 \\
\hline Desistiram da oral . & 一 & 一 & $\mathbf{5}$ \\
\hline Não fizeram oral . & 1 & 1 & 6 \\
\hline Não fizeram escripta . & 1 & 1 & 1 \\
\hline Já fizeram esta cadeira & 108 & 101 & 15 \\
\hline & 189 & 189 & 189 \\
\hline
\end{tabular}

Inscriptos 154

Dir. Civil Dir.Commercial Dir. Jud. Civil M. Legal

Promovidos . . . . 9

Approvados . . . $\quad$. $71 \quad 71$

32

Reprovados. . . . . $15 \quad 28$

Nâo compareceram á oral 2 . 2

Não fizeram escripta. . - -

$\begin{array}{lllll}\text { Já fizeram esta cadeira } . & 57 & 28 & 40 & 43\end{array}$

$\overline{154} \quad \overline{154} \quad \overline{154} \quad \overline{154}$

De 3 a 21 de dezembro realizaram-se os exames de 1." epoca.

As commissões examinadoras foram as seguintes:

1. cano: - Profs. Drs. Jorge Americano, Alexandre Correia, M. F. Pinto ,Pereira e S. Soares de Faria;

2. anno: - Profs. Drs. Antionio de Sampaio Doria, Lino de Moraes Leme e Noé Azevedo;

3. anno: - Profs. Drs. Jorge Americano, Ernesto de Moraes Leme e Noé Azevedo;

4. anno: - Profs. Drs. Francisco Morato, Honorio Monteiro e A. Almeida Junior;

5. anno: - Profs. Drs. Raphael Sampaio, Mario Masagão, Gabriei de Rezende Filho e Jorge Americano.

Foi o seguinte o resultado desses exames:

Matriculados 341

1. $\quad$ ANNO

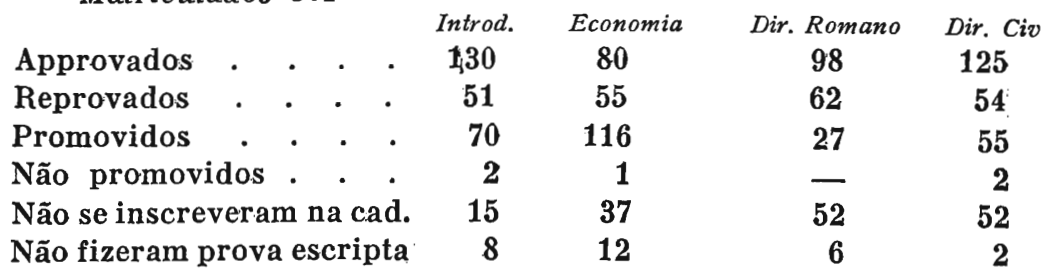




\begin{tabular}{|c|c|c|c|c|}
\hline & & Dir. Civil & Dir. Penal & Constituciona \\
\hline Não compareceram á oral & 15 & 18 & 27 & 19 \\
\hline Não obtiveram frequencia. & 5 & 9 & 6 & 11 \\
\hline Não obtiveram media . & 45 & 13 & 63 & 21 \\
\hline & 341 & 341 & 341 & 341 \\
\hline
\end{tabular}

Matriculados 316

\section{$2 .^{\circ}$ ANNO}

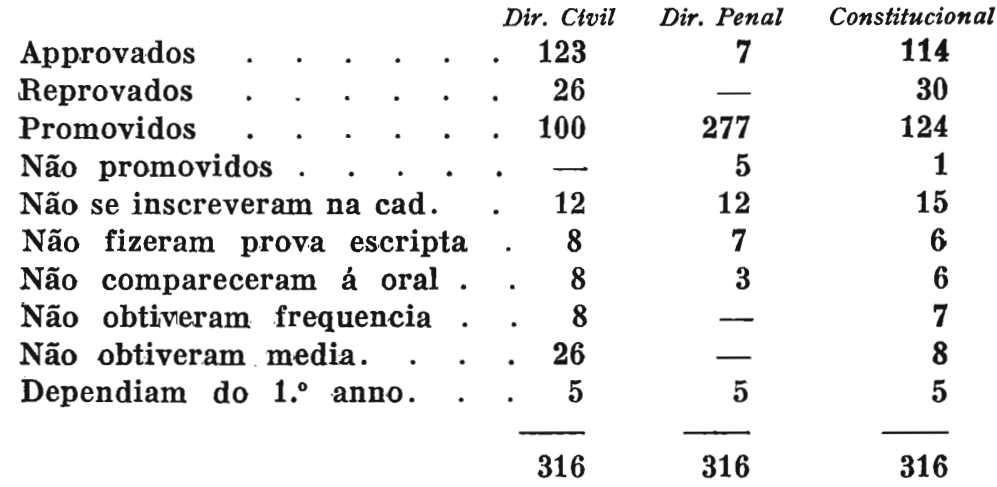

Matriculados 237

\section{ANNO}

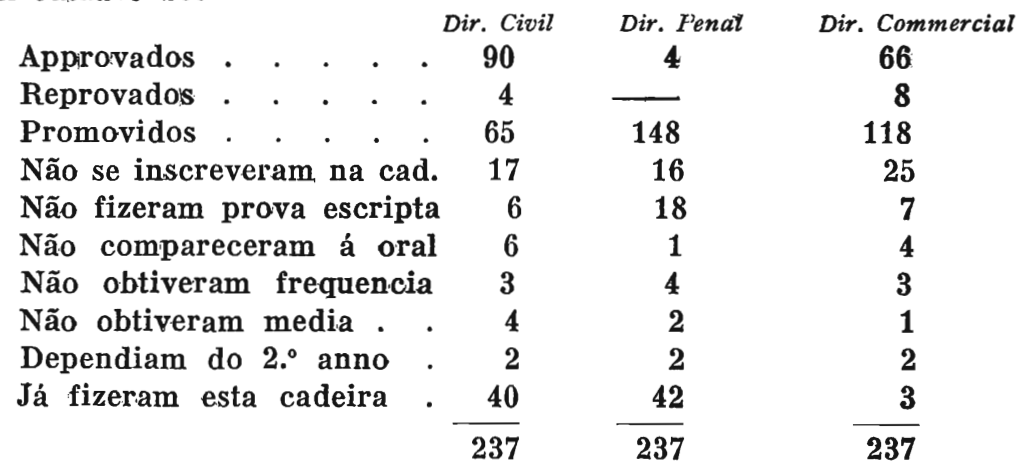

Matriculados 298

\section{$4 .^{\circ}$ ANNO}

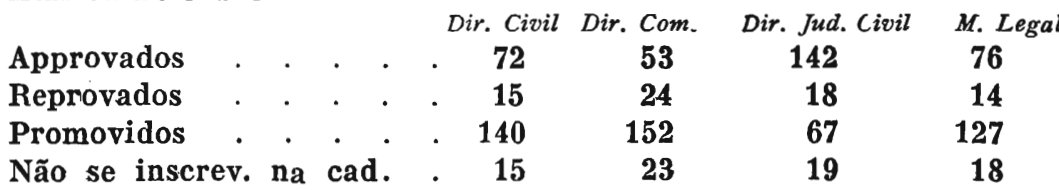




\begin{tabular}{|c|c|c|c|c|}
\hline fiz. prova escripta. & Dir. Civil & Dir. Com. & Dir. Jud. Civil & M. Lega \\
\hline Não compar. á oral. & $\begin{array}{l}21 \\
33\end{array}$ & 10 & 11 & 9 \\
\hline Não obtiveram frequencia. & 1 & 1 & 3 & 2 \\
\hline Não obtiveram media & 3 & 5 & 2 & 10 \\
\hline Fallecido . . . . . . & 1 & 1 & 1 & 1 \\
\hline Já fizeram esta cadeira. & 26 & 19 & 24 & 25 \\
\hline Dependiam do $3 .^{\circ}$ anno. & 1 & 1 & 1 & 1 \\
\hline & 298 & 298 & 298 & 298 \\
\hline
\end{tabular}

Matriculados 226

5. ANNO

Approvados . Dir. Civil Dir. Jud

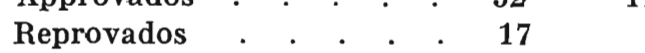

Promovidos . . . . . 131

Desistiu da oral . . . . 1

Não compareceram á oral . $\quad 3$

Não se inscreveram na cadeira 17

Não foi chamado á oral.

Não obtiveram media e freq. 11

Não fizeram prova escripta.

$\begin{array}{rrrr}4 & 4 & 3 & 2\end{array}$




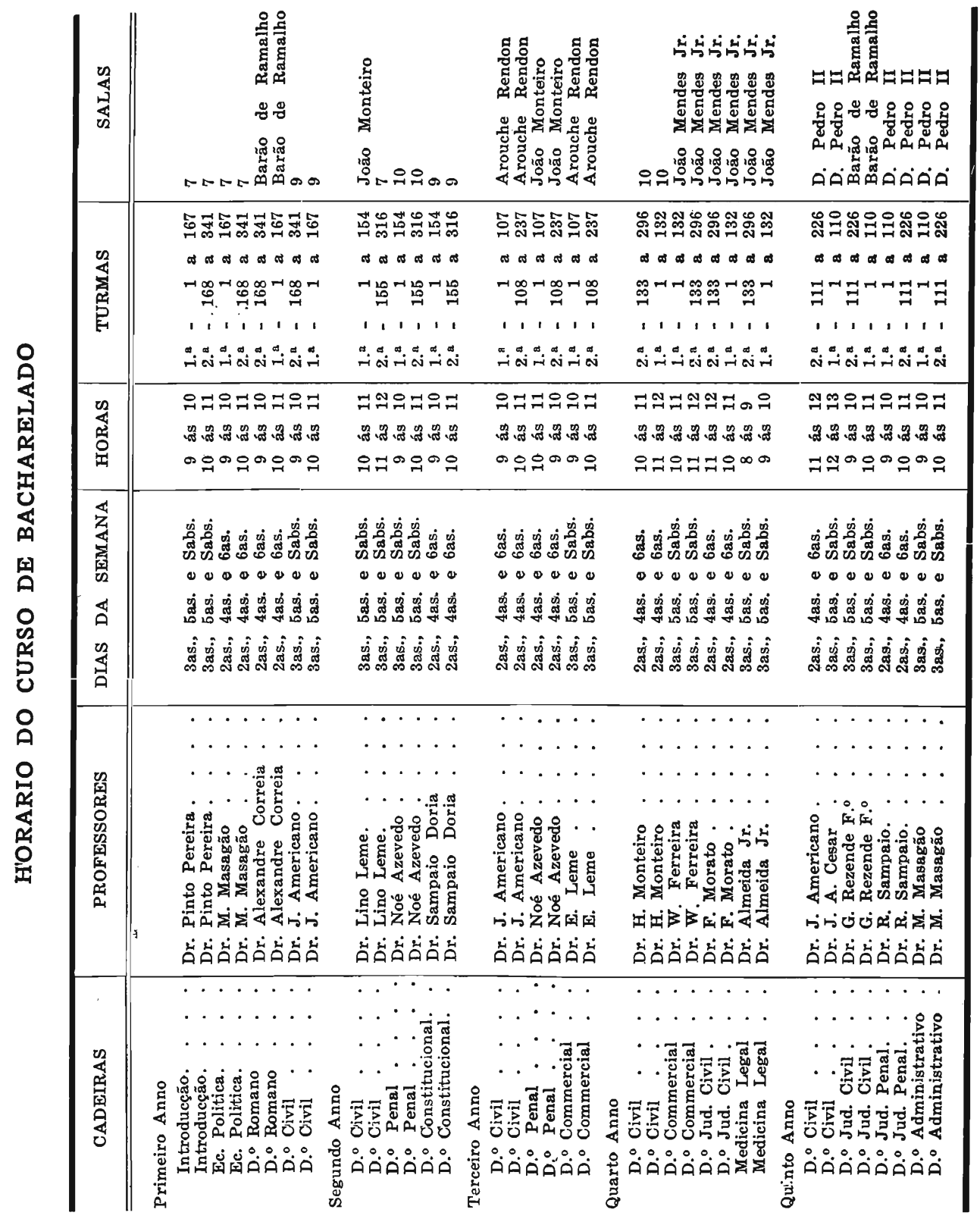




\section{$-199-$ \\ GURSO DE DOUTORADO}

Matricularam-se no $10^{\circ}$ anno deste curso 22 alumnos, os quaes não apresentaram os trabalhos regulamentares, ou não alcançaram a freqoencia necessaria, pelo que não se'realizaram exames de 1." epoca.

Os profs. que leccionaram neste curso foram os seguintes:

Profs. Antonio de Sampaio Doria (Direito Publico - Theoria Geral do Estado e partes especiaes); Theophilo Benedicto de Sousa Carvalho (Historia do Direito Nacional); Braz de Sousa Arruda (Direito Civil Comparado) e Manoel Carlos de Figueiredo Ferraz (Criminologia), todos no $1 .^{\circ}$ anno.

0 2. anno não funccionou por falta de alumnos.

o Horario do Curso de Doutorado foi o seguinte:

\begin{tabular}{|c|c|c|c|c|}
\hline CADEIRAS & PROFESSORES & $\begin{array}{l}\text { DIAS DA } \\
\text { SEMANA }\end{array}$ & HORAS & SALAS \\
\hline 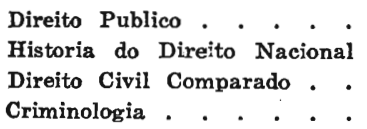 & $\begin{array}{l}\text { Dr. A. de Sampaio Doria } \\
\text { Dr. T. B. Souza Carvalho } \\
\text { Dr. Braz de S. Arruda } \\
\text { Dx. M. C. Figueiredo Ferraz }\end{array}$ & $\begin{array}{l}\text { 3as. e 5as. } \\
\text { 2as. e 4as. } \\
\text { 2as. e 4as. } \\
\text { 3as. e 5as. }\end{array}$ & $\begin{array}{l}17-18 \\
18-19 \\
17-18 \\
18-19\end{array}$ & $\begin{array}{l}\text { J. Mendes Jr. } \\
\text { J. Mendes Jr. } \\
\text { J. Mendes Jr. } \\
\text { J. Mendes Jr. }\end{array}$ \\
\hline
\end{tabular}

\section{PESSOAL ADMINISTRATIVO}

Registraram-se durante o anno os seguintes factos:

\section{NOMEAÇס̃ES}

- O Sr. Antonio Constantino para chefe da Bibliotheca, decreto de $10 / 4$ (exercicio a 22/4); , a Snra. Da. Maria Leite Veiga para quarta escripturaria, interina, decreto de $6 / 4$ (exercicio a 6/5); o Snr. Francisco Emygdio Pereira Neto para quarto escripturario, interino, decreto de 24/5 (exercicio a 27/5); o Snr. Manoel Ribeiro de Almeida para servente, em portaria de 22/4, (exercicio a 22/4); Snr. Cesar Pereira Vianna para servente, em portaria de $8 / 7$, (exercicio a 8/7); o Snr. Maximiliano Menezes para servente, em portaria de 8/7 (exercicio a 8/7); o Snr. Manoel Ribeiro de Almeida para servente effectivo, em portaria de 8/7 (exercicio a 8/7); o Snr. Amaro Antonio de Araujo para servente, em portaria de 8/7 (exercicio a $8 / 7)$; o Snr. Jayme Pontes para servente, em portaria de $8 / 7$ (exercicio a 8/7); o Snr. Cassio Ignacio da Silva para servente, em portaria de 8/7 (exercicio a 8/7) ; o Snr. Amelio Ignacio Dilles para servente, em portaria de $8 / 7$ (exercicio a 8/7); o Snr. Bernardo Stonoga para ascensorista, acto de 18/7 (exercicio a 20/7). 


\section{PROMOÇбES}

- 0 Snr. Flavio Mendes, de auxiliar de secretario a secretario, acto de 6/4 (exercicio a 22/4); o snr. Raul Assumpção Sampaio de chefe de secção a auxiliar de secretario, acto de $30 / 4$ (exercicio a 2/5; o bach. Julio de Barros, de $10^{\circ}$ escripturario a chefe de secção, acto de 30/4 (exercicio a 2/5); o Snr. Frederico Baptista de Sousa, de $2 .^{\circ}$ a $10^{\circ}$ escripturario, acto de $30 / 4$ (exercicio a $2 / 5$ ); o bach. Durval Rebouças, de 3.0 a 2..$^{\circ}$ escripturario, acto de 6/4 (exercicio a 22/4); o Snr. Geraldo da Silva Leite, de 3.० a $20^{\circ}$ escripturario, acto de $30 / 4$ (exercicio a 2/5); o Snr. Pedro Athanazio da Silva, de $4 .^{\circ}$ a $3 .^{\circ}$ escripturario, acto de $6 / 4$ (exercicio a 22/4); o Snr. Adolpho Schmidt Junior, de $4 .^{\circ}$ a $3 .^{\circ}$ escripturario, acto de $30 / 4$ (exercicio a 2/5); o Snr. Pedro Arruda Mello, de continuo a bedel, por acto de 5/7 (exercicio a 8/7); o Snr. Jesuino Rodrigues, de servente a continuo, acto de 15/7 (exercicio a 22/7); o Snr. Luiz Gonzaga Nazareth, de servente a continuo, acto de 18/7 (exercicio a 20/7).

\section{SUBSTITUIÇס̃ES}

O Snr. Flavio Mendes, quando auxiliar de secretario, exerceu interinamente o cargo de secretario, de $10^{\circ}$ de janeiro a 21 de abril.

o Snr. José Fernandes Moreno substituiu, de 7 a 21 de abril, o Chefe da Bibliotheca.

O Snr. Luiz Gonzaga Nazareth substituiu o continuo Milton Milfont, de $10^{\circ}$ de janeiro a 19 de julho.

o Snr. Jeronymo Teixeira da Silva substituiu, durante todo o anno, o bedel Abelardo Rodrigues.

\section{EXONERAÇб̄ES}

Foram exonerados a pedido:

- O Snr. Leonel Vaz de Barros, de chefe technico da Bibliotheca (deixou o exercicio em 6 de abril); o Snr. José Fernandes Moreno, de auxiliar technico da Bibliotheca (c/exercicio até 4/7); o Snr. Milton Milfont, de continuo (18/7); o Snr. Aulette Penteado, de continuo (15/1/36) e o Snr. Flavio Graça, de servente (deixou o exercicio em 28/6).

\section{CONTRACTOS}

Foram contractadas para a Bibliotheca da Faculdade:

Donas Ady Pinheiro Cortez, Lilly Dale Terrel e Noemia Corrêa Conceição (em 6/7), Maria José do Amaral Santos (em 29/8) e Rosa 
Sophia Gennari (em 13/11), para os serviços de dactylographia $e_{\text {, }}$ tambem, como dactylographas sómente para o periodo nocturno, as Snras. Donas Conceição Negrão e Juracy Cardoso de Almeida Barros (em 13/11).

\section{AUGMENTO DE VENGIMENTOS, CONVERSÃO E CREAÇÃO DE CARGO}

Em decreto $n .^{\circ} 7.288$, de 5 de julho de 1935 , foi creado mais um logar de bedel nesta Faculdade, convertido no de encarregado de expediente um logar de 2.9 escripturario e fixados novos vencimentos para o Chefe Technico da Bibliotheca, auxiliar technico e contador, vencimentos esses que ficaram sendo os seguintes:

Chefe Technico da Bibliotheca. . 20:400\$000 annuaes

Auxiliar Technico da Bibliotheca . 12:000\$000 annuaes

Contador. . . . . . . . . 12:000\$000 annuaes

Encarregado do Expediente . . 12:000\$000 annuaes

\section{SECRETARIA}

Papeis protocollados durante o anno . . . . . . . . $\quad 5430$

Papeis sahidos . . . . . . . . . . . . . . 574

Officios da Faculdade ao Governo Estadoal . . . . . 120

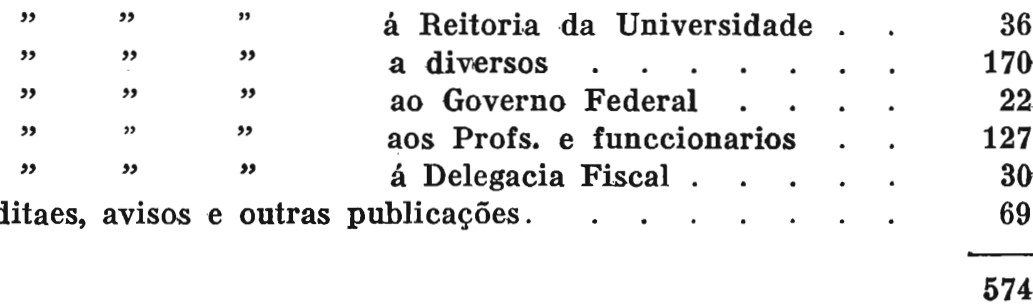

A Secretaria expediu, durante o anno, 32 cartas de bachareis e 2 de doutor (vide annexo $n .^{\circ}$ 2) e 1.729 certidões.

\section{ALMOXARIFADO}

Exerceu, durante o anno, o cargo de Almoxarife, o 2.0 escripturario Geraldo da Silva Leite.

O Almoxarifado attendeu a 697 requisições e effectuou 114 recebimentos, pagos pela Faculdade, e 68, por intermedio do Almoxarifado da Secretaria da Educação e Saúde Publica. 


\section{REVISTA DA FACULDADE}

Foram eleitos pela Congregação, no dia 9 de março, os Profs. Drs. Mario Masagão, Honorio Fernandes Monteiro e Alexandre Correia para a commissão de redacção da Revista.

Sob a orientação dessa commissão, foram publicados os fasciculos I - II - III e IV, que compõem o volume XXXI, de 1935.

\section{SECRETARIO DA REVISTA}

O Snr. Leonel Vaz de Barros exerceu este cargo de $10^{\circ}$ de janeiro a 6 de abril, data em que foi exonerado a pedido.

Em portaria de 9 de abril, foi nomeado o Snr. Flavio Mendes para exercer o cargo (exercicio naquella mesma data).

Acerca das attribuições desse cargo, disse o Snr. Sergio Milliet da Costa e Silva, quando no exercicio delle, o seguinte:

" $E$ indispensavel que a Revista continue a ser publicada trimestralmente.

Sei quanto é difficil faze-lo. Ao Secretario da Revista competirá obter as colaborações e isso lhe custará tempo e expediente. Sem a constante preocupação da Revista, não lhe será possivel bota-la na rua nas datas certas. E ainda imprescindivel que não discuide da secção bibliografica. A bibliografia publicada tem dado otimos resultados e trazido doações importantes. Nem sempre, porém, os profs. ajudam. E preciso que o secretario da Revista faça, ás vezes, a critica, submetendo-a apenas aos profs. Na Revista, as secções de pareceres e trabalhos universitarios é que devem merecer os maiores carinhos. São a parte da atualidade".

Parece-nos que a Revista deverá ser publicada quadrimestralmente, afim de que os fasciculos reunam maior collaboração, desenvolvendo-se mais as secções bibliographicas, de pareceres e trabalhos universitarios.

\section{COLLEGIO UNIVERSITARIO}

\section{Corpo docente:}

São profs. deste Collegio, nesta data, os Snrs.:

Latim - Profs. Manoel Francisco Pinto Pereira e Zulmiro Ferraz de Campos.

Hygiene - Prof. Vicente de Paulo Melillo.

Logica - Prof. José Domingos Ruiz (interino).

Literatura - Prof. Antonio de Salles Campos.

Philosophia - Prof. Padre José de Castro Neriy.

Biologia - Prof. Zeferino Vaz. 
Sociologic - Prof. Antenor Romano Barreto.

Geographia - Profs. Aroldo de Azevedo (interino).

Historia da Civilização - Prof. Plinio Corrêa de Oliveira.

Psychologia - Prof. João Baptista Damasco Penna.

Economia - Prof. Octavio Paranaguá (interino).

\section{Nomeações:}

No anno de 1935, foram nomeados para este curso os Snrs.:

- José Domingos Ruiz, para a cadeira de Logica, decreto de 14 de maio (posse a 22/5);

- Pedro Egydio de Carvalho para a cadeira de Economia, decreto de 20 de maio (posse a 28/5);

- Octavio Paranaguá para a cadeira de Economia, decreto de 22 de agosto (posse a 2/9); e

- Aroldo de Azevedo para a cadeira de Geographia, decreto de 20 de setembro (posse a 25/9).

Janeiro a Abril:

\section{Substituições :}

- O Prof. Ignacio Benevides de Rezende substituiu ao Prof. Plinio Corrêa de Oliveira, na cadeira de Historia da Civilização;

- O Prof. Ruy Calazans de Araujo substituiu ao Prof. Plinio Corrêa de Oliveira, na 2. ${ }^{a}$ turma da cadeira de Historia da Civilização;

- 0 Prof. Octavio Paranaguá substituiu ao Prof. Clovis Ribeiro, na cadeira de Economia.

Maio a Julho:

- O Prof. José Domingos Ruiz substituiu, a partir de 22 de maio, ao Prof. da cadeira de Logica, Prof. Armando Prado, por estar este commissionado com prejuizo dos vencimentos;

- O Prof. Pedro Egydio de Carvalho substituiu o Prof. da cadeira de Economia, de 28 de maio em diante.

Agosto:

— O Prof. José Domingos Ruiz substituiu ao Prof. da cadeira de Logica;

- O Prof. Pedro Egydio de Carvalho substituiu ao Prof. da cadeira de Economia até o dia 5 de agosto;

Setembro a Dezembro: Logica;

O Prof. José Domingos Ruiz substituiu ao Prof. da cadeira de 
Economia;

- O Prof. Aroldo Azevedo, nomeado em 20/9, regeu a cadeira de

- O Prof. Octavio Paranaguá, nomeado em 22/8, regeu a cadeira de Geographia.

\section{Commissionamentos :}

O Prof. Armando da Silva Prado esteve em commissão junto ao Ministerio da Justiça, de abril a dezembro.

\section{Exonerações :}

- O Prof. Candido de Moraes Leme foi exonerado, a pedido, por decreto de 13/8;

- O Prof. Pedro Egydio de Carvalho deixou o exercieio do seu cargo em 5/8.

\section{Corpo discente:}

\section{Alumnos matriculados:}

Matricularam-se neste Collegio, no anno de 1935, 228 alumnos (vide relação nominal annexa) sendo:

na $10^{\mathrm{a}}$ serie . . . . . . . . . . . . . 156

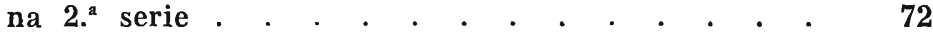

Exames e promoções:

1. ${ }^{\mathrm{a}}$ Serie - Matriculados . . . . 156

Approvados, inscriptos em 1." época . . • . . . 53

Approvados, que não se inscreveram . . . . . 18

Dependem de uma ou duas cadeiras . . . . . 26

Dependem de todas as cadeiras . . . . . . . 9

Não obtiveram media e frequencia . . . . . . 50

2. ${ }^{\mathrm{a}}$ Serie - Matriculados . . . . 72

Approvados, inscriptos em $1 .^{\text {a }}$ época . . . . . $\quad$. 29

Approvados, que não se inscreveram . . . . . 4

Dependem de uma ou duas cadeiras . . . . . 26

Dependem de todas as cadeiras . . . . . . . . 6

Não obtiveram media e frequencia. . . . . . 7 


\section{EXAMES DE PREPARATORIOS}

De accordo com a lei $\mathrm{n}^{\circ} 23$, de 11 de fevereiro de 1935 , realizaram-se exames de preparatorios nesta Faculdade, nos dias 14 e 15 de março, concorrendo aos mesmos seis (6) candidatos que requereram 14 exames.

Compuzeram as commissões examinadoras os professores Raphael Corrêa de Sampaio, Domingos de Vilhena Moraes e Sylvio Dias da Silveira.

$O$ resultado desses exames vae em annexo.

Secretaria da Faculdade de Direito da Universidade de São Paulo, 29 de janeiro de 1936.

Flavio Mendes.

Secretario

ANNEXO N.० 1

EXAMES GERAES DE PREPARATORIOS

Inscriptos: 6

\begin{tabular}{|c|c|c|c|c|c|c|c|c|}
\hline & Lat. & $\begin{array}{c}\text { Hist. } \\
\text { do } \\
\text { Brasil }\end{array}$ & $\begin{array}{c}\text { Chorog. } \\
\text { e Cos- } \\
\text { mogra- } \\
\text { phia }\end{array}$ & $\begin{array}{l}\text { Fran- } \\
\text { cez }\end{array}$ & $\begin{array}{c}H . \text { Uni- } \\
\text { versal }\end{array}$ & Inglez & $\begin{array}{c}\text { Physica } \\
\text { e Chi- } \\
\text { mica }\end{array}$ & Nat. \\
\hline Approvados . . . & 1 & 2 & 1 & 1 & 3 & - & - & 1 \\
\hline Reprovados . . . . . & - & 1 & - & - & - & 1 & 1 & 1 \\
\hline $\begin{array}{c}\text { Não compareceram á } \\
\text { prova oral. . . . }\end{array}$ & - & - & - & - & 1 & - & - & \\
\hline Jà fizeram esta materia & 5 & 3 & 5 & 5 & 2 & 5 & 5 & 4 \\
\hline Total dos candidatos & 6 & 6 & 6 & 6 & 6 & 6 & 6 & 6 \\
\hline
\end{tabular}


ANNEXO N: 2 RELAÇÃO DOS DIPLOMAS DE BACHAREL EXPEDIDOS NO
ANNO DE 1935

\begin{tabular}{|c|c|c|c|c|c|}
\hline BACHAREL & & & Natural de & $\begin{array}{c}\text { Collaçáo de } \\
\text { Grau }\end{array}$ & $\begin{array}{c}\text { Expedição } \\
\text { do } \\
\text { Diploma }\end{array}$ \\
\hline Alcindo Bueno Assis. & . & & São Paulo & 21-12 & $30-12$ \\
\hline Aldo Lupo . . . . . . . & . & & $"$ & $10-12$ & $13-' 2$ \\
\hline Alfredo de Moraes Sarmento & . . & & , & $17-3-25$ & $23-2$ \\
\hline Alonso Annibal da Fonseca. & . . & & $"$ & $1^{\prime}-2$ & 23-2 \\
\hline Alvaro Blumenthal. . . . & . & & $"$ & 21-12 & 30-12 \\
\hline Angelo José Simões de Arruda & a. & & $"$ & $22-3$ & $25-3$ \\
\hline Antonio Augusto Firmo da Silv & va. & & $"$ & 21-12 & $30-12$ \\
\hline Antonio Carlos do Amaral & . . & & 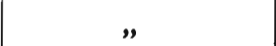 & $14-3$ & 20-3 \\
\hline Augusto Cesar Barreto . . & . & . & Cid. Rio de Janeiro & $15-12-34$ & $2-1$ \\
\hline Celso Guimarães da Fonseca & . & . & São Paulo & $5-8$ & $10-8$ \\
\hline Dalmo Godoy Araujo . . . & . & . & $"$ & $7-8$ & $9-8$ \\
\hline Diogenes Rolim de Albuquerqu & ue & & $"$ & 21-12 & $30-12$ \\
\hline Eulalio Firmo da Silva & . & . & , & $12-12$ & $30-12$ \\
\hline Fausto Floriano de Toledo & . . & . & " & $21-12$ & $30-12$ \\
\hline Fernando Mendes de Almeida & Jr. & . & Distrito Federal & $3-5-02$ & $7-6$ \\
\hline Francisco Bertino de Almeida $\mathrm{P}$ & Prado & & São Paulo & $2-3$ & $15-3$ \\
\hline Francisco Toledo Piza & .. & . & " & 21-12 & $30-12$ \\
\hline Francisco Falleiros. . & . & & ., & $11-12$ & $13-12$ \\
\hline Gabriel Silveira Faro . . . & . & . & Sergipe & 21-12 & $30-12$ \\
\hline Geraldo Mendonça de Barros & . & . & Minas Geraes & 21-12 & $31-12$ \\
\hline Hamilton Dragomiroff Franco & . & . & Paraná & $21-12$ & $31-12$ \\
\hline Leven Vampré $. \quad . \quad . \quad$. & . & . & São Paulo & $14-12-12$ & 25-7 \\
\hline Luiz Oliva de Toledo. . & . & . & $"$ & 5-12-14 & 25-2 \\
\hline Manoel Eduardo Pereira . & $\cdot$ & . & , & $2-3$ & $15-3$ \\
\hline Olyntho Guastini . . . . . & . & . & " & $19-3-32$ & $4-2$ \\
\hline Paulo Augusto do Nascimento & . . & . & Rio Grande do Sul & $29-3$ & $1-7$ \\
\hline Paulo de Tarso Corrêa de Sam & mpaio & . & São Paulo & $19-3-32$ & $13-4$ \\
\hline Renato Taglianetti . . . & . . & & " & $27-9$ & $2-10$ \\
\hline Ruy de Lima e Castro & . & & ., & $9-3$ & $15-3$ \\
\hline Salathiel de Almeida Filho & $\cdot$ & $\cdot$ & Minas Geraes & $10-12-34$ & $2-1$ \\
\hline Sylvestre de Lima Filho . . & $\cdot$ & - & São Paulo & $31-12-35$ & $5-2$ \\
\hline Sinval Gonçalves de Oliveira & . & 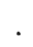 & Goyas & $4-6-35$ & - \\
\hline Alexandre Correia (1). . . & 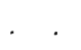 & & Portugal & $10-12-3$ & - \\
\hline Sebastião Soares de Faria (2) & & . & São Paulo & $10-12-3$ & - \\
\hline
\end{tabular}

$\overline{\text { NOTA : }}-1$ e 2 - Diplomas de Doutor. 


\section{RELATORIO DA THESOURARIA}

A Thesouraria funccionou nos dias de expediente, sem interrupção, durante todo o anno de 1935.

Dentre os serviços, por ella attendidos, cumpre destacar: a arrecadação das taxas no periodo que antecede a abertura dos cursos; na occasião do segundo recolhimento de taxas (2..$^{\circ}$ semestre) e no periodo de exames, como épocas em que redobra o seu serviço normal. Facto este, que tambem acontece nos primeiros dias de cada mez, em que attende ao pagamento das folhas de vencimentos. Essas follhas, que comprehendem vencimentos de Professores e funccionarios do quadro, de turmas desdobradas, de serviços nocturnos, de dactylographas contratadas, e de serventes extra numerarios, com pequenas variações, alcançaram a importancia mensal de rs. 63:250\$000, distribuidos por 135 pagamentos mensaes.

Arrecadando as taxas de todos os 1.668 alumnos da Faculdade distribuidos pelos cursos de Doutorado e Bacharelado, Collegio Universitario, e dos candidatos a exames vestibulares, que, em 1935, attingiram a 357, foi intensissima essa parte do expediente da Thesouraria. Accresce notar, que esse trabalho ainda se tornou mais complexo, pela restituição, que a Thesouraria teve de effectuar, das differenças de taxas originadas da reducção, feita pelo Governo do Estado, depois de já iniciada a 1.a arrecadação. Entretanto, tudo se fez com absoluta regularidade, dentro dos horarios e dias designados pelos editaes, attendendo, ainda, a Thesouraria, no decorrer do anno, ao recolhimento de taxas em atrazo, de depositos e emolumentos de diplomas, aviamentos, certidões, venda de publicações, recebimento de juros de apolices, e ao serviço de pagamentos.

0 movimento de recebimentos de certidões e de venda de publicações foi o seguinte:

CERTIDÕES : 1.729 certidões diversas cujos emolumentos produzidos foram $23: 935 \$ 000$.

VENDA DE PUBLICAÇOESS: 90 revistas, 152 annuarios e 60 programmas diversos, que produziram o total de 2:230\$000.

A Thesouraria recebeu, durante o anno, a importancia total de rs. 380:408\$100 do Thesouro do Estado para pagamento da Folha de Pessoal do Quadro e, para attender ás despesas de prompto pagamento, doze adeantamentos mensaes de 1:000\$000. Dessas parcellas já prestou contas, devendo receber quitação de dez adeantamentos mensaes de 1:000\$000.

Da mesma repartição, recebeu, a titulo de adeantamento em dinheiro rs. 400:000\$000, além de tres promissorias do valor global de 615:999 $\$ 900$ por conta do credito especial aberto pelo Governo 
Estadual. Estes dois ultimos recolhimentos foram feitos em nome do Exmo. Sr. Director, a quem foram concedidos os adeantamentos.

As taxas de maior volume arrecadadas pela Thesouraria foram as do Curso de Bacharelado, distribuidas como segue:

$$
\begin{aligned}
& \text { 1. Anno Renda Ordinaria . . . . . 104:865\$000 }
\end{aligned}
$$

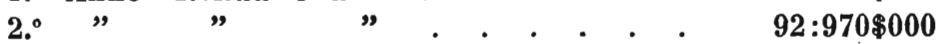

$$
\begin{aligned}
& 3 .^{\circ} " \quad " \quad . \quad . \quad . \quad . \quad . \quad . \quad 57: 945 \$ 000
\end{aligned}
$$

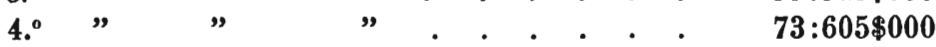

$$
\begin{aligned}
& \text { 5. } " \quad " \quad . \quad . \quad . \quad . \quad . \quad . \quad 61: 940 \$ 000 \\
& \text { Total: } \quad 391: 325 \$ 000
\end{aligned}
$$

Em consequencia da reducção feita pelo Governo do Estado, a Thesouraria effectuou as seguintes restituições, por conta dessas taxas:

$$
\begin{aligned}
& \text { 1. Anno Restituições a clumnos . . . } 20: 990 \$ 000 \\
& 2.0^{\circ} \quad " \quad " \quad \text {. } \quad \text {. . . . } \quad 8: 530 \$ 000
\end{aligned}
$$

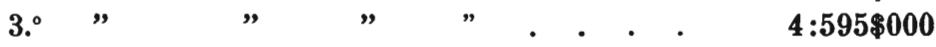

$$
\begin{aligned}
& 4 .^{\circ} \quad " \quad " \quad \cdots \quad . \quad . \quad . \quad . \quad 3: 195 \$ 000 \\
& 5 . " \quad " \quad \cdots \quad \cdots \quad . \quad . \quad . \quad . \quad 660 \$ 000 \\
& \text { Num total de rs. } 37: 970 \$ 000
\end{aligned}
$$

Apezar do grande serviço a cargo da Thesouraria e que frequentemente se prolongou muito além da hora normal do expediente, é com satisfação que consignamos ter sido elle desempenhado com toda regularidade e dentro da observancia fiel das normas estabelecidas.

Deste modo, a Thesouraria sempre encerrou o "Caixa" diariamente, fazendo a conferencia do saldo em especie e enviando, rigorosamente, todos os dias, á Contadoria, o Boletim diario, do movimento da Caixa, acompanhado dos respectivos comprovantes.

Iniciado o exercicio com um saldo em Caixa de rs. 5:586\$190, as entradas de numerario, durante o correr do anno, attingiram a rs. $3.011: 873 \$ 210$.

Durante o mesmo anno as sahidas de numerario ascenderam a 2.968:456\$100, fechando o "Caixa", em 31 de dezembro de 1935, com o saldo de 49:003\$300, por onde se vê, que, nesse anno, o gyro total de numerario, pela Thesouraria, foi de rs. 3.017:459\$600.

São estas, Exmo. Sr. Director, em breve relatorio, as informações acerca das principaes occorrencias registradas em 1935, nos serviços da Thesouraria, a meu cargo, no desempenho do qual appliquei o melhor de meus esforços. 


\section{RELATORIO DA CONTADORIA}

0 movimento de Contabilidade, relativo ao exercicio de 1935 , abrange o periodo que vae de $10^{\circ}$ de janeiro de 1935 a 28 de fevereiro de 1936, data em que se encerra o exercicio financeiro de 1935 . de accordo com as normas da contabilidade do Estado. Desta forma o presente relatorio não traz os dados definitivos do encerramento do exercicio que serão apresentados com o fechamento do balanço geral e respectivas demonstrações. Apenas o relato das principaes occorrencias até 31 de dezembro incluindo uma demonstração dos saldos das verbas orçamentarias e dos titulos dos livros de Desdobramento da Receita e da Despeza, naquella data. A apreciação geral dos resultados do exercicio será feita após o seu encerramento.

1 - MOVIMENTO DE ALUMNOS: Durante o exercicio de 1935 as taxas escolares dos alumnos soffreram uma reducção, após o inicio da sua arrecadação. Teve assim a Contadoria de organisar o serviço de restituição das differenças de taxas, o que foi feito, de accordo com a Thesouraria, com toda regularidade e exactidão. Registradas essas differenças nas fichas individuaes de conta corrente dos alumnos, ficaram creditadas áquelles que não as retiraram, tendo sido feito o encontro de contas por occasião do recolhimento de taxas do 2..$^{\circ}$ semestre. Esse serviço fez-se com toda segurança, mercê do fichario individual, acima alludido, pelo qual se acompanha a situação economica do alumno na Faculdade.

Por occasião dos recolhimentos de taxas a Contadoria forneceu á Thesouraria e á Secretaria a relação dos alumnos devedores, credores e dispensados, extrahida do fichario.

Organisou, tambem, por elle, a demonstração das taxas recolhidas no $10^{\circ}$ semestre, para effeito do calculo da quota que cabia á Reitoria da Universidade.

Em 31 de dezembro foi tirada a relação de debitos para abertura dos talões de taxas de 1935 que serão recolhidas em 1936.

Registrou tambem os prazos concedidos aos alumnos para quitação de seus debitos.

2 - EXECUÇÃO ORÇAMENTARIA: A execução do orçamento do Estado fez-se por empenhos e adeantamentos, acompanhando-se pelo livro de "Verbas Orçamentarias" o seu desenvolvimento. Manteve a Contadoria constantes entendimentos com a Secretaria da Educação e Thesouro do Estado, para boa execução orçamentaria, obedecendo-se ás. normas regulamentares.

Organisou com a Thesouraria as prestações de contas dos adeantamentos mensaes, encaminhando-as ao Thesouro do Estado. 
Encaminhou á Secretaria da Educação, devidamente conferidas e escripturadas as contas a pagar pelo Thesouro, por conta dos Creditos Orçamentarios.

3 - OFFICIOS A SECRETARTA DA EDUCAÇÃO: Foram expedidos até 31 de Dezembro, 48 (quarenta e oito) officios á Secretaria da Educação, relacionados com o serviço da Contadoria, para pedidos de empenhos, adeantamentos, fornecimentos de material e encaminhamentos de contas.

4 - ORÇAMENTO PARA 1936: A contadoria elaborou e apresentou as bases para organisação do orçamento da Faculdade para 1936, fornecendo os dados que se faziam necessarios.

5 - OBRAS DE REFORMA: As obras de reforma cujo total ascendia em 31 de Dezembro de 1934, a rs. 1.051:422\$075, proseguiram custeadas pela Faculdade, até Setembro de 1935, que, nesse titulo applicou, de suas rendas, mais a importancia de rs. 473:442\$900. De Setembro a 31 de Dezembro, as Obras já foram custeadas pelo Governo do Estado, com um credito especial de rs. 800:000\$000 que foi aberto para esse fim. Por conta desse credito já foram applicados: até 31 de Dezembro de 1935, rs. 581:478\$500. Attinge assim, em 31 de Dezembro de 1935, incluindo-se os pagamentos feitos anteriormente a esse anno, a rs. 2.106:343\$475 o montante das despezas com as obras de edificação.

6 - QUOTA A REITORIA DA UNIVERSIDADE: Foi recolhida a quota correspondente ao $10^{\circ}$ semestre. Ha a recolher a quantia correspondente ao $2 .^{\circ}$ semestre, cuja apuração está sendo feita.

7 - RENDA PATRIMONIAL: A renda patrimonial, proveniente de juros de apolices attingiu a rs. 52:800\$000, dos quaes $34: 300 \$ 000$ foram recebidos da Delegacia Fiscal pelo Sr. Thesoureiro e 18:500\$000 recebidos no Rio de Janeiro, por intermedio do Banco do Commercio e Industria de S. Paulo.

As contas correntes bancarias produziram de juros em 1935, $9: 623 \$ 700$ dos quaes $8: 281 \$ 100$ provenientes da liquidação em 29-3-35, da conta a prazo fixo, que a Faculdade mantinha com o Banco Commercial do Estado de S. Paulo.

Nesta data a Faculdade não possue depositos a prazo fixo. As suas disponibilidades figuram enumeradas em topicos sob rubrica. especial.

8 - PROMISSORIAS DO GOVERNO DO ESTADO: Em poder da Faculdade, emittidas em nome do Exmo. Sr. Director, continuavam ainda em 31-12-35, duas promissorias do valor nominal cada uma de 205:333\$300 e 208:000\$000, com vencimentos para, respectivamente, 25-3-36 e 25-5-36, relativas a adeantamentos por conta do credito especial aberto para esta Faculdade. 
9 - RENDA E DESPEZA - A arrecadação de rendas em 1935 produziu $639: 852 \$ 710$. A despeza, até 31 de Dezembro foi de rs. $1.063: 844 \$ 500$, nella computada as restituições de taxas aos alumnos. A differença que se registrou, entre as rendas e despezas, foi coberta pelos saldos do exercicio anterior, accrescidos do credito especial de 200:000\$000, concedido pelo governo do Estado.

Estes dados ficam sujeitos a pequenas alterações até o fechamento do balanço geral, por occasião do encerramento do exercicio. 10 - SALDOS DISPONIVEIS EM 31 DE DEZEMBRO DE 1935: - São os seguintes os saldos disponiveis em 31-12-35:

Em apolices:

Valor nominal de 1.056 apolices federaes do valor de 1:000\$000 cada uma

$1.056: 000 \$ 000$

Em Caixa: .

Em bancos assim distribuidos:

Banco do Brasil . . . 1:774\$300

Banco Comercial . . . 11:101\$800

Banco S. Paulo . . . $3: 267 \$ 200$

Banco C. Ind. . . . . $66: 382 \$ 300 \quad 82: 525 \$ 600 \quad 131: 528 \$ 900$

Foi regularmente feita durante o anno, a conferencia das contas a pagar e pagas, folhas de Pessoal, e arrecadações. de 1935.

$E^{\prime}$ o que me cumpre informar, nesta data, sobre o movimento Cassio José de Toledo

\section{RELATORIO DA CHEFIA TECHNICA DA BIBLIOTHECA}

Exmo Sr. Dr. Francisco Morato.

DD. Director da Faculdade de Direito ida Universidade de São Paulo.

Em obediencia á determinação verbal de V. Excia., tenho a honra de, com a necessaria vênia, apresentar-lhe o relatorio do movimento e dos trabalhos verificados, durante o anno de 1935, nesta Bibliotheca actualmente sob a minha chefia.

\section{SITUAÇÃO EM QUE ENCONTREI A BIBLIOTHECA}

Nomeado pelo Governo do Estado, assumi o cargo de chefe technico em 22 de abril de 1935, e, conforme tive occasião de com- 
municar a V. Excia. pela exposição escripta de 20 de maio do mesmo anno, encontrei a quasi paralysação de alguns serviços e a paralysação de outros, com graves prejuizos para este departamento. 0 atrazo provinha, segundo me pareceu de inicio, da deficiencia do numero do pessoal e, tambem, da mudança que, do velho para o novo edificio da Faculdade, acabava de ser feita. Mas observei, a seguir, que a secção technica, por falta de melhor apparelhamento, não poude desenvolver a sua actividade, do que resultou o accumulo de cerca 100 mil fichas de obras - parte das quaes por ser tabellada e parte por ser revista - além do retardo de outros serviços de urgencia. Feita a mudança pelo illustre ex-chefe technico professor Leonel Vaz de Barros, trabalho nunca assás encarecido, deixou o meu antecessor o cargo por ter sido nomeado para outra funcção publica, e isso contribuiu a que mais se desorganisasse a secção technica. Encontrei mais de 500 obras para serem classificadas e fichadas; cerca de 2.500 jornaes para recorte e fichagem; e innumeros fasciculos e volumes de revistas e publicações diversas para a fichagem de artigos de doutrina.

Além disso o pó invadia a sala dos livros, e os volumes cobriamse de môfo nas estantes. Por falta de pessoal, cessára a secção biblioiatrica. Era impossivel manter em dia a limpesa. Tambem a desinfecção não dava resultados satisfactorios. Apareciam, a cada momento, volumes corroidos por traças e carunchos. A desinfecção por meio da estufa thermo-chimica sómente, era insufficiente. Indispensavel completar-se o serviço com a desinfecção á mão, por meio de pincelagens de fórmulas especiaes.

Ataquei, no que me foi possivel, os trabalhos da secção technica, porém, notando o entrave do andamento da Bibliotheca em vista do numero exiguo de pessoal, tive a honra de expor a V. Excia. a necessidade da reorganisação dos serviços, com o augmento de funccionarios.

Entrementes, a Bibliotheca era desfalcada de dous funccionarios: uma quarta escripturaria dactylographa, addida, que voltou para a secretaria da Faculdade, e um continuo, que se exonerou. E, logo depois, o antigo auxiliar technico tambem deixava o cargo, vaga essa que foi devidamente preenchida com o contracto de dactylographas.

Com o augmento de quatro dactylographas - tres para a secção technica, e uma para o expediente - e quatro serventes, foram activados os serviços, porém, não ainda com aquelles resultados objectivados pela chefia technica e imposta pelo desenvolvimento deste instituto.

Não obstante a dedicação de todos os funccionarios, os serviços continuavam deficientes, não só porque o numero de pessoal 
era sempre exiguo, mas tambem porque as horas de trabalho não bastavam para se conseguir a realisação material imprescindivel. A medida que se adentrava nos serviços, verificava-se que havia muito mais por ser feito do que se previra. Ambos os catalogos existentes - um o methodico e outro o onomastico - estavam em retardo, não correspondendo á realidade das obras archivadas. Dahi a conveniencia de serem totalmente refeitos. Na representação escripta, datada de 31 de julho, pela qual submetti á alta apreciação de V. Excia. o alvitre dos serviços extraordinarios em periodo nocturno, foi assim resumido o plano dos serviços de maior urgencia :

1) Fichagem em atraso - Comprehende a tabellagem de cerca de 60 mil fichas, sendo $30 \mathrm{mil}$ das do catalago methodico, por materia, 30 mil das do catalogo onomastico: São fichas que não figuram nos catalogos, porque não têm, ainda, a ubicação. Este serviço demanda, mais, a reforma das fichas guias, com o accrescimo de fichas remissivas, pois o estado actual do fichario onomastico deixa muito a desejar. No serviço de tabellagem está incluida, tambem, a revisão da redacção da ficha, revisão que é feita á vista de cada obra.

2) Revisão do indice alphabetico, por materia - Este indice nāo corresponde, exactamente, á classificação decimal adoptada. De maneira que se registam, a miude, enganos e lacunas prejudiciaes aos consultantes. $O$ indice abrange cerca de 2 mil fichas e precisa ser inteiramente refeito. E' trabalho demorado, visto como depende da revisão do catalogo methodico.

3) Revisão do catalogo methodico - $\mathrm{O}$ plano deste serviço abrange: a) uniformisação e b) actualisação. São mais de 50 mil fichas que esperam revisão cuidada. Tambem as fichas seccionaes precisam ser revistas e refeitas na maior parte. Além disso, ha urgencia de desdobramentos projectados, consequencia logica do augmento do numero das fichas.

4) Revisão do catalogo onomastico - Segue a mesma orientação do plano acima. Outras $50 \mathrm{mil}$ fichas.

5) Revisão das fichas abandonçdas - Acham-se abandonadas, em uma das estantes da livraria, conforme V. Excia. teve opportunidade de verificar pessoalmente, cerca de 10 mil fichas antigas que devem passar pelo crivo da revisão, depois de reclassificadas e tabelladas. Isso sómente se conseguirá á vista de cada obra.

6) Fichagem de recortes de jornaes e de artigas de revistas E grande o numero de fichas que, em ambos os catalogos, devem ser feitas dos recortes dos jornaes e dos artigos das revistas, publicações essas recebidas no corrente anno e até hoje. Mesmo o exame das antigas colleções de revistas mostra que enorme quantidade de 
artigos não foi classificada nem tabellada nem fichada analyticamente. E não é exaggero calcular em 5 mil o montante das fichas correspondentes a este item.

7) Obras não classificadas nem fichadas - Existem na Bibliotheca centenas e centenas de volumes que não figuram nos catalogos. São volumes antigos que ficaram de banda possivelmente por occasião da mudança para o novo edificio da Faculdade.

8) Classificação e fichagem das obras que entram diariamente - Em pouco mais de mez, cerca de 400 volumes entraram para a Bibliotheca, sem que houvesse tempo de classifical-os e fichal-os. Até o fim do anno mais de mil obras ficarão nas mesmas condições, sem se contar o vulto dos recortes dos jornaes e dos artigos das revistas por serem classificados e fichados. Alguns milhares de fichas deverão sahir desse trabalho. Note V. Excia., ainda, que ahi não figura a catalogação das duplicatas, a coordenação das theses e dissertações dos antigos alumnos da Faculdade de Direito, a parte biblioiatrica, etc., serviços esses que seguirão o seu curso concomitantemente com os acima discriminados.

V. Excia. teve ensejo de verificar, pessoalmente, a exactidão do que reclamava a chefia technica.

Quanto ao desencontro de catalogos e livros, a prova está nas tres fichas que vão em annexo. Vê-se, por exemplo, que cinco artigos, de cinco autores diversos, são fichados como de um só... Em outra, o estudo "Da Posse", de Ribas, tinha a ficha de um volume de "O Direito" apenas, quando abrange varios, tomos daquella publicação... E, finalmente, na terceira ficha a redacção "analphabetico" em logar de "analphabeto"... Subiam a centenas as fichas que, no catalogo onomastico, assim se apresentavam, o que provou a necessidade de serem refeitos os catalogos.

Com o serviço extraordinario do periodo nocturno e o augmento de novas dactylographas contractadas, a secção technica achou-se em condições de proseguir o plano de refazimento dos catalogos e por em dia o serviço atrasado.

\section{CATALOGO ONOMASTICO}

Foi o primeiro atacado. Refeito, já, até a letra S, com a inclusão de mais de 30 mil fichas tabelladas e tambem feitas de novo, provavelmente será concluido até março proximo. Quasi todas as fichas, em vista da redacção incompleta que apresentavam, foram conferidas com as obras, exigindo grande attenção e cuidado. Cinco dactylographas, nisso se occupam, com capacidade e competencia. 
O catalogo onomastico terá fichas seccionaes de obras e materias mais procuradas, de modo que muito facilitará a consulta.

Terminado esse, será iniciada a reorganisação total do catalogo methodico que abrange quasi o dobro das fichas do onomastico.

\section{MOVIMENTO DE CONSULTAS}

No decorrer de 1935, o movimento de consultas, no periodo diurno, attingiu o total de 28.347 contra 16.240 do anno de 1934 . Houve, portanto, o augmento de 12.107 consultas.

A frequencia foi de 16.591 estudantes, 4.013 pessoas estranhas á Faculdade, 7.643 leitores de jornaes e 109 consultas por correspondencia.

Foram consultadas 25.476 obras, em 30.076 volumes, na maioria sciencias juridicas e sociaes.

O periodo nocturno, inaugurado em setembro, registou, até 31 de dezembro, 2.633 consultas.

Nesse periodo a frequencia foi de 1.354 estudantes, 712 pessoas estranhas á Faculdade e 567 leitores de jornaes.

Foram consultadas 2.446 obras, em 2.709 volumes, na maioria sciencias juridicas e sociaes.

Nos dois periodos as consultas chegaram ao total de 30.980 .

O movimento consta dos mappas mensaes e do mappa annual remettidos a V. Excia.

Afim de estender a divulgação e propaganda da Bibliotheca, organisei o serviço de publicidade semanal, endereçado á imprensa e ás estações radiodiffusoras. Com a boa vontade do jornal e do radio, a propaganda tem sido efficaz. Em annexo vae a relaçāo dos jornaes e das radiodiffusoras que gentilmente divulgam os communicados.

\section{ENCADERNAÇÕES E RECONSTITUIÇŐES}

$\mathrm{Na}$ officina annexa á Bibliotheca foram feitas 1.033 encadernações e 258 reconstituições.

Fóra, foram feitas 799 encadernações.

\section{OUTRAS ENTRADAS}

Entraram, em 1935, 1.342 obras e 346 revistas.

Das obras mencionadas, 210 por compra, 789 por doação e $34 \%$ por permuta com duplicatas da Bibliotheca e com a "Revista da Faculdade de Direito de São Paulo". 


\section{JORNAES}

A Bibliotheca recebe, diariamente, cerca de 80 jornaes, de todos os pontos do Brasil. Desses, 34 por iniciativa desta chefia. Não sem esforço obtive a remessa de todos os órgans da imprensa desta capital e da federal.

\section{SECÇÃO TECHNICA}

A secção technica vem realisando regularmente os seus serviços, não obstante o atrazo em que se encontrou na epoca já referida.

A classificação está a cargo, unica e exclusivamente, do chefe technico, visto como é impraticavel o desdobramento desse serviço, que é o mais importante, por outros funccionarios.

A fichagem está entregue ás habilissimas dactylographas, sob o meu controle.

Logo que se concluir o catalogo onomastico, será ultimada a revisão das fichas abandonadas com a mudança, o que tem impedido a consulta de numerosos livros.

As secções de consulta de obras e jornaes, e, bem assim a dos catalogos, continuam sob o controle desta chefia. Igualmente, a de biblioiatria.

Com a nomeação de outro secretario da Commissão de Redacção da "Revista da Faculdade de Direito de São Paulo", à Bibliotheca está affecto, apenas, o encargo de divulgar e distribuir essa publicação e remettel-a, em consignação, ás livrarias desta capital. A arrecadação da venda dos exemplares da "Revista" é feita directamente pela thesouraria da Faculdade.

\section{EXPEDIENTE}

Sob o controle da chefia technica, o expediente está entregue ao encarregado sr. Agilulpho Candido Dias, funccionario habil e diligente, cujo serviço nada deixa a desejar.

0 expediente tem feito, com regularidade, a distribuição da "Revista" e do "Annuario", da Faculdade, conforme se verifica dos annexos.

\section{CORRESPONDENCIA}

0 movimento da correspondencia da Bibliotheca, em 1935, foi o seguinte: cartas e officios recebidos, 251; cartas e officios expedidos, 3.036; total, 3.287. 


\section{CAIXA DE SELLOS}

As despesas de sellos e outros sommaram, em 1935, a importancia de rs. 1:788\$500.

\section{REQUISIÇŐES DE MATERIAL}

Foram feitas, durante $o$ anno de 1935, varias requisições de material, ao Almoxarifado da Faculdade, consoante é demonstrado em annexo.

\section{MOVEIS E UTENSILIOS}

A' requisição desta chefia, a Bibliotheca foi mais bem apparelhada internamente, não só no mobiliario, como tambem com a acquisição de diversas machinas dactylographicas, etc., o que vae minuciosamente exposto no inventario junto.

\section{PESSOAL}

Presentemente, é o que segue o quadro do pessoal da Bibliotheca:

1 - Chefe Technico......... Antonio Constantino

2 - Encar. do expediente .... Agilulpho Candido Dias

3 - 3..$^{\circ}$ Escripturario ........ Herculano Salgado de Mello

4 - " $" \quad \ldots \ldots \ldots$ João Pedro V. Pacheco

$5-4 .^{\circ} \quad " \quad \ldots \ldots \ldots$ Miguel R. de F. Guimarães

6 - Dactyl. contractada ...... Noemia C. Conceição

7 — " $" \quad \ldots \ldots \ldots$ Lilly Dale Terrell

8 - " $" \quad \ldots \ldots \ldots$ Ady Pinheiro Cortez

9 - $" \quad$ " $\quad$ "...... Maria José do A. Santos

10 - $" \quad$ "...... Rosa Sofia Gennari

11 - $" \quad$ " $\quad \ldots \ldots \ldots$ Juracy C. de A. Barros

12 - " $" \quad \ldots \ldots \ldots$ Conceição Negrão

13 - 3. ${ }^{\circ}$ Escrip. addido........ Adolpho Schmidt Junior

14 - Bedel .............. Elias A. Rodrigues

15 - $" \quad \ldots \ldots \ldots \ldots \ldots \ldots \ldots$ Pedro Arruda Mello

16 - Continuo ............ Jesuino Rodrigues

17 - $"$. ........... Aulette Penteado

18 - Servente ........... Max Meneses

19 - $" \quad \ldots \ldots \ldots \ldots \ldots \ldots$ Jayme Pontes

20 - $" \ldots \ldots \ldots \ldots \ldots$ Amelio Ignacio Dilles 


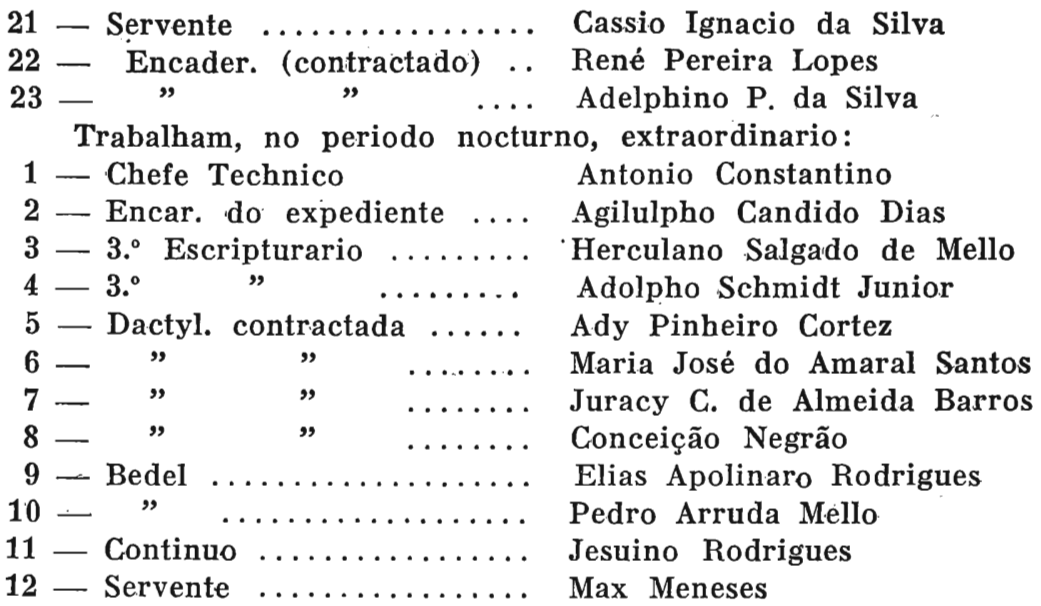

No correr de 1935, verificaram-se as seguintes alterações no quadro do pessoal : em 6 de abril, exoneração, a pedido, do professor Leonel Vaz de Barros do cargo de chefe technico; em 20 do mesmo mez, nomeação do actual chefe technico; em 28 de junho, exoneração, a pedido, do servente Flavio Graça; em 3 de julho, desligação da dactylographa addida Maria Leite Veiga; em 7 de julho, promovido a bedel o continuo Pedro Arruda Mello; em 6 de julho contractadas as dactylographas Ady Pinheiro Cortez, Lilly Dale Terrell e Noemia Corrêa Conceição; em 8 de julho, contractados os serventes Cassio Ignacio da Silva, Jayme Pontes e Amelio Ignacio Dilles; na mesma data, nomeado o servente Maximiliano Meneses; em 21 de julho promovido a continuo o servente Jesuino Rodrigues; em 15 do mesmo mez, exonerado, a pedido, José Fernandes Moreno, do cargo de auxiliar technico; em 29 de agosto, contractada a dactylographa Maria José do Amaral Santos; em 5 de novembro, entra em goso de tres mezes de licença o continuo Aulette Penteado; na mesma data, designado para o serviço extraordinario do periodo nocturno o $3 .^{\circ}$ escripturario Adolpho Schmidt Junior; em 13 de novembro, contractadas, as datylographas Rosa Sophia Gennari, Conceição Negrão e Juracy Cardoso de Almeida Barros.

Desistiram do serviço extraordinario, do periodo nocturno, o quarto escripturario Miguel Rogerio de Freitas Guimarães, em 8 de outubro; o continuo Aulette Penteado, em 30 de outubro; e a dactylographa contractada, Noemia Corrêa Conceição, em $10^{\circ}$ de.novembro.

Tiveram 15 dias de ferias regulamentares o $3 .^{\circ}$ escripturario 
João Pedro da Veiga Pacheco, em 15 de novembro; e o $4 .^{\circ}$ escripturario Miguel Rogerio de Freitas Guimarães, em 6 de dezembro.

Bibliotheca da Faculdade de Direito da Universidade de S. Paulo, em 1.0 de Janeiro de 1936.

\section{COM OS ANNEXOS}

I - 3 fichas onomasticas.

II - Quadro demonstrativo do movimento de 1935, no periodo diurno.

III - Quadro demonstrativo do movimento de 1935, no periodo nocturno.

IV - Relação dos jornaes e das estações de radio que têm divulgado, semanalmente, os communicados da Bibliotheca.

V - Relação dos trabalhos executados na officina de encadernação.

VI — Relação dos livros entrados em 1935.

VII - Relação das obras entradas por compra, doação e permuta em 1935.

VIII - Relação das pessoas que fizeram doações á Bibliotheca.

IX - Relação de permutas de duplicatas.

$\mathrm{X}$ - Relação dos jornaes recebidos em 1935.

XI - Movimento geral da correspondencia.

XII - Movimento das despesas da caixa de sellos e outros.

XIII - Relação das requisições feitas ao almoxarifado da Faculdade de Direito.

XIV - Quadro do pessoal dos periodos diurno e nocturno.

XV - Designações de serviço, nomeações, exonerações, etc.

XVI - Relação das pessoas, editores, jornaes, revistas e instituições que recebem a "Revista da Faculdade de Direito".

XVII - Relação dos exemplares da "Revista" remettidos, em consignação, por intermedio da Bibliotheca, ás livrarias da capital.

XVIII - Relação das instituições que recebem o "Annuario da Faculdade de Direito".

XIX - Inventario dos moveis e utensilios existentes na $\mathrm{Bi}$ bliotheca. 


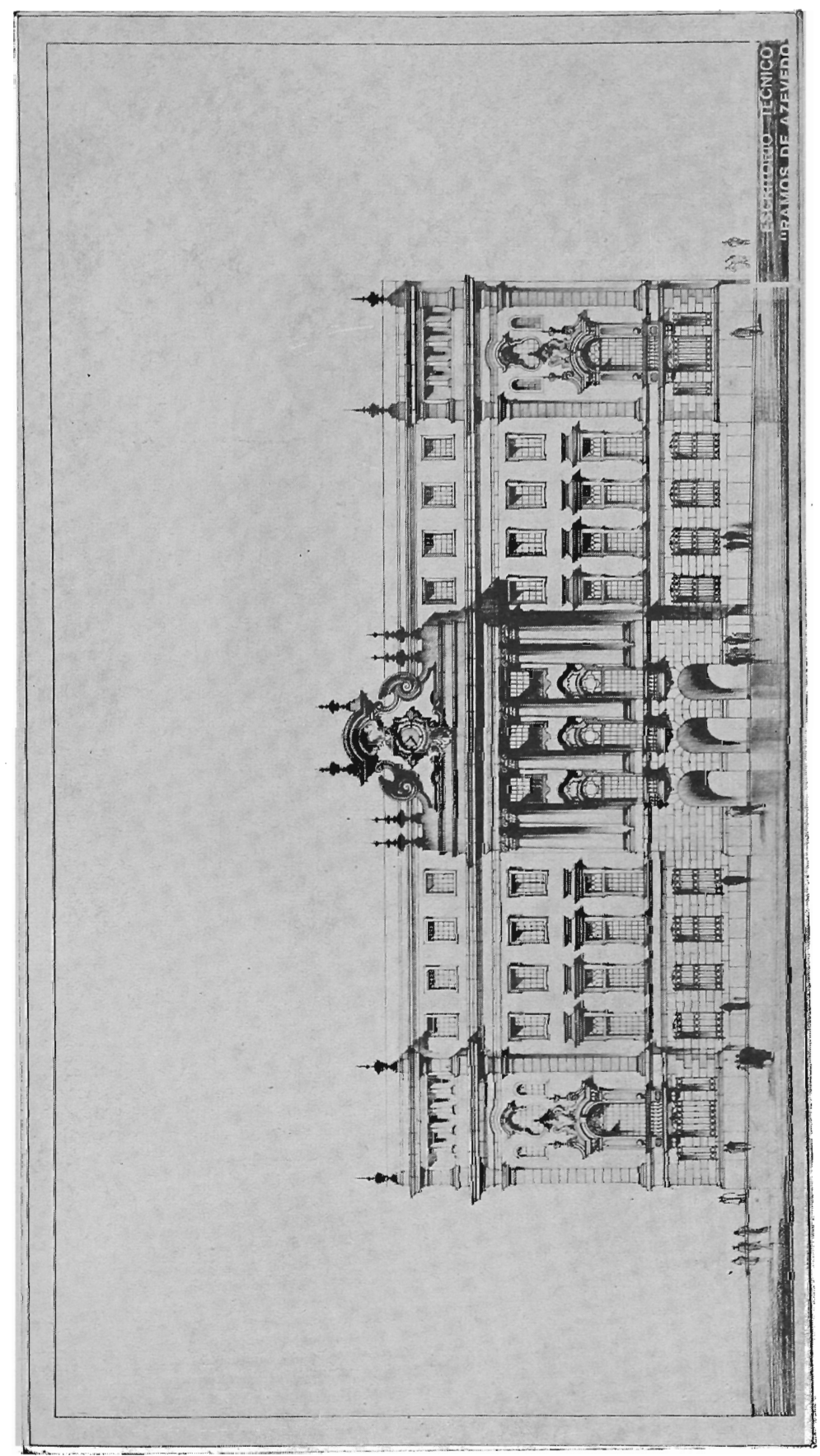




\section{2. $\quad$ PAVIMENTO}

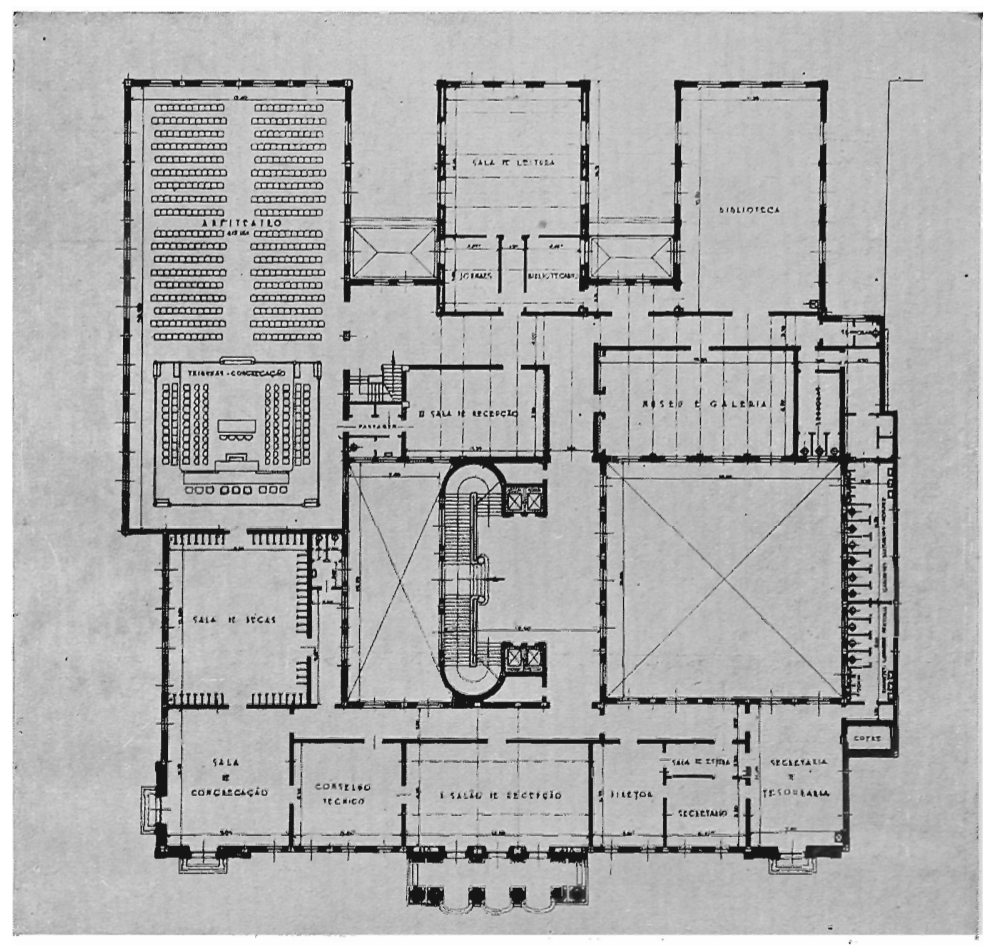




\section{PAVIMENTO}

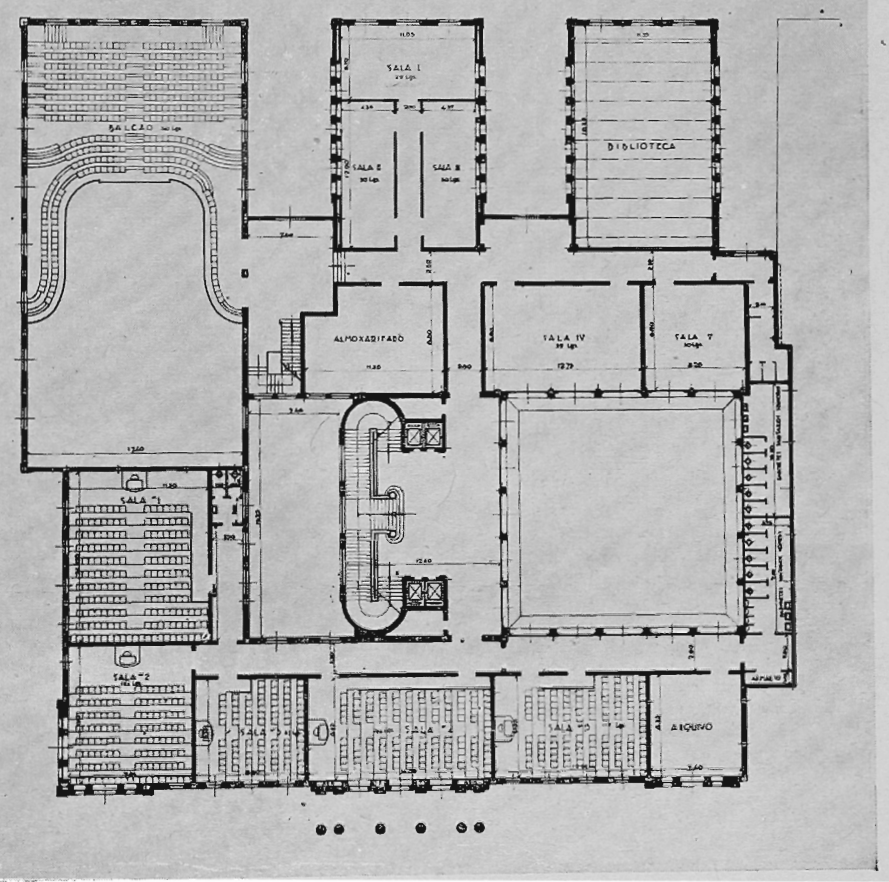




\section{4. ${ }^{\circ}$ PAVIMENTO}

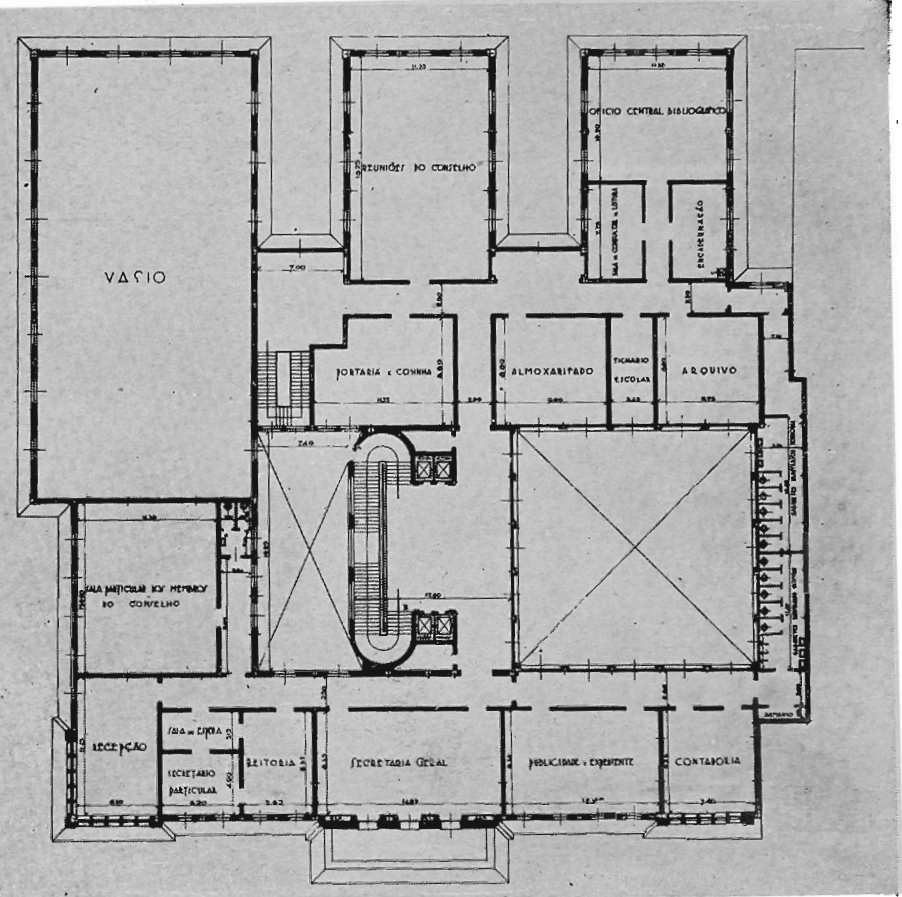




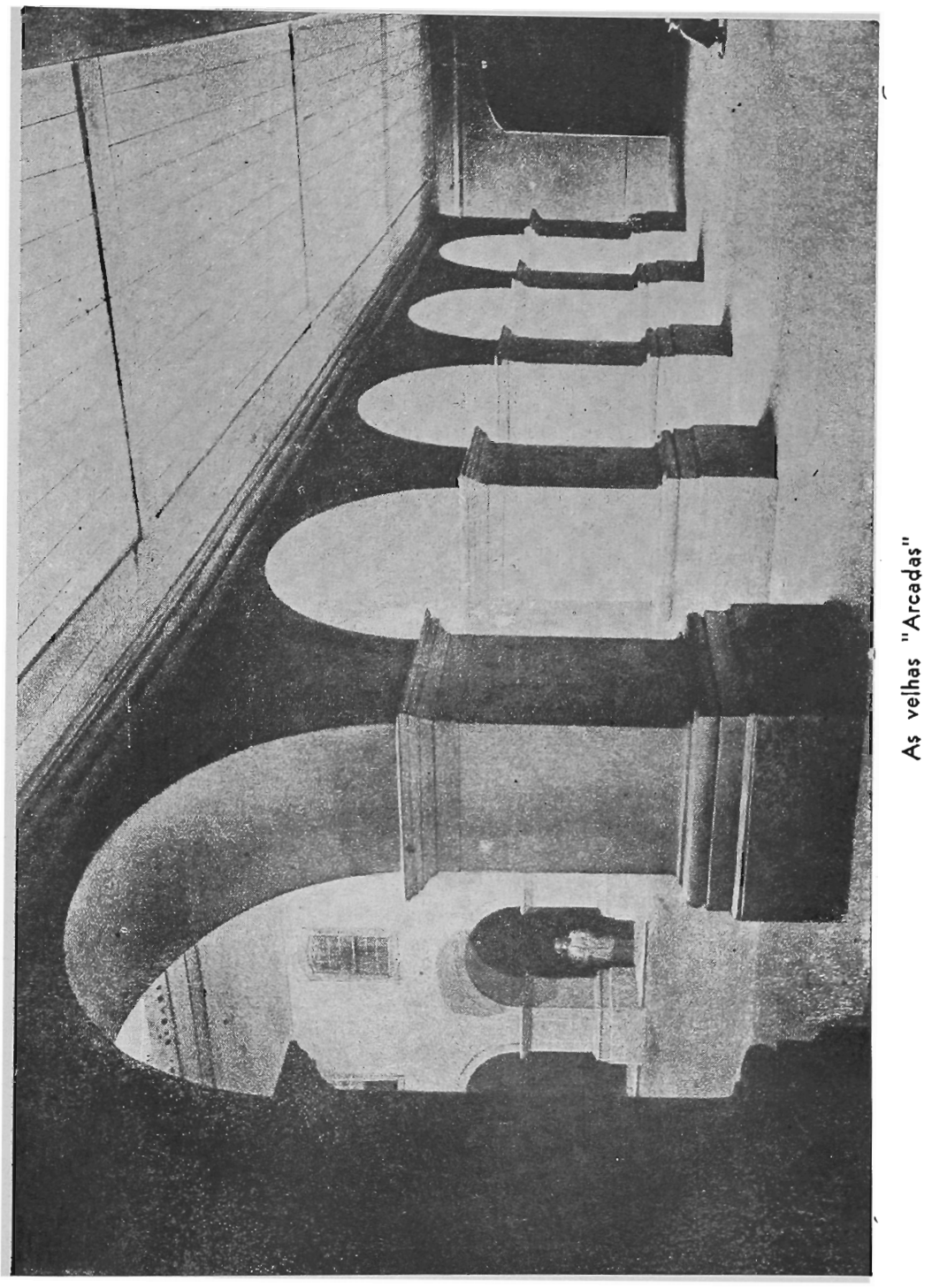




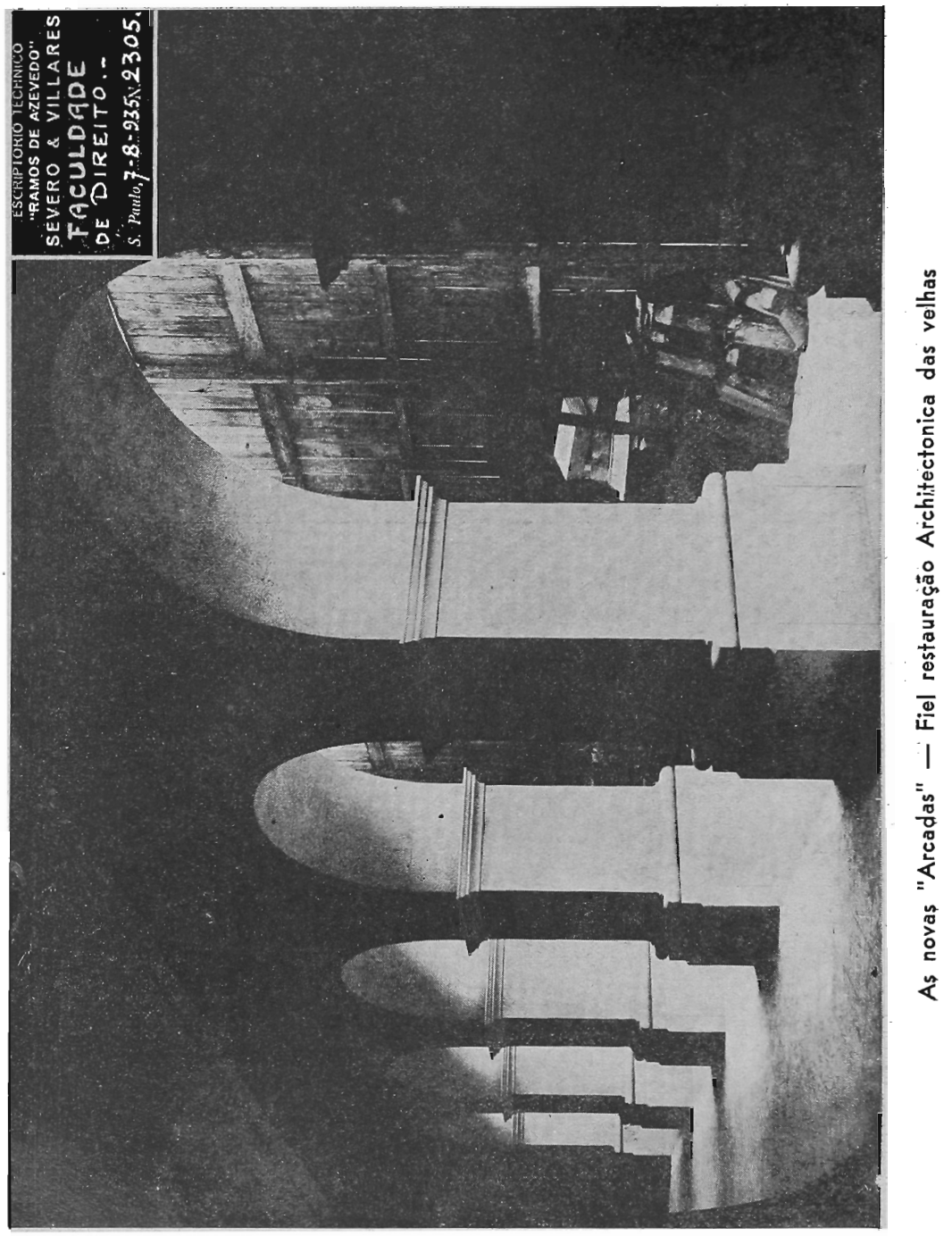




\begin{tabular}{|c|c|c|c|c|c|c|c|c|c|c|c|c|c|c|c|c|c|c|c|c|c|c|c|c|c|c|c|c|c|c|c|c|c|c|}
\hline \multirow[b]{2}{*}{ MEses } & \multicolumn{4}{|c|}{ LEITORES } & \multirow[b]{2}{*}{ 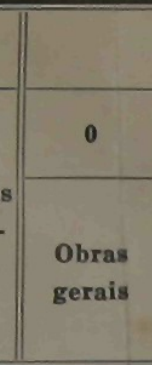 } & \multirow[b]{2}{*}{$\mid$\begin{tabular}{c|}
1 \\
Filiosoffia
\end{tabular}} & \multicolumn{9}{|c|}{ OB R A $\mathrm{s}$} & & \multirow[b]{2}{*}{\begin{tabular}{|l|}
$\begin{array}{c}\text { Total } \\
\text { ode } \\
\text { obras }\end{array}$ \\
\end{tabular}} & \multirow[b]{2}{*}{$\begin{array}{c}\text { Total } \\
\text { voled } \\
\text { volumes }\end{array}$} & \multicolumn{2}{|c|}{$\begin{array}{l}\text { MEDIA DIARA } \\
\text { DA CONSULTA }\end{array}$} & \multicolumn{7}{|c|}{ LING UAS } & \multicolumn{3}{|c|}{ OBRAS ENTRADAS } & \multicolumn{3}{|c|}{ SERVICO DE OFICINA } & \multirow[b]{2}{*}{ OBSERYAGGES } \\
\hline & $\begin{array}{c}\text { Eattu- } \\
\text { dantes }\end{array}$ & 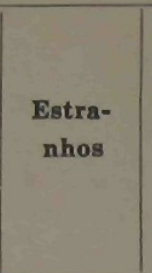 & 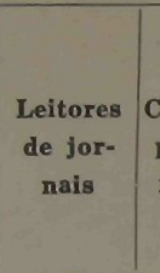 & 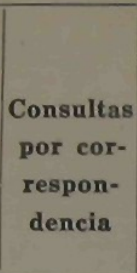 & & & 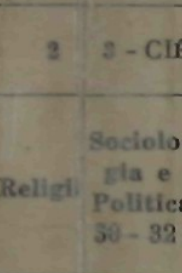 & 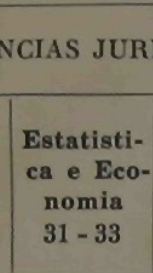 & $\begin{array}{l}\text { Directo } \\
31-35\end{array} \mid$ & 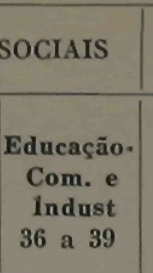 & $\begin{array}{l}\text { Filo- } \\
\text { logia }\end{array}$ & 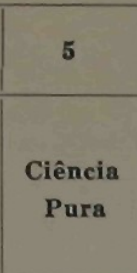 & 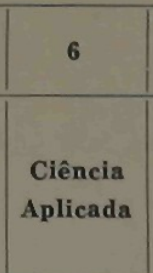 & $\begin{array}{c}\text { Belas } \\
\text { Artes }\end{array}$ & $\frac{8}{\substack{\text { Literas } \\
\text { tura }}}$ & 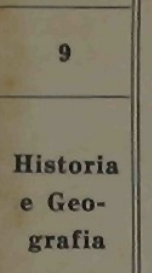 & & & 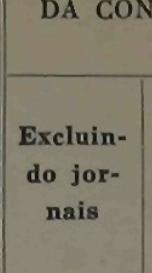 & $\begin{array}{l}\text { Media } \\
\text { geral }\end{array}$ & 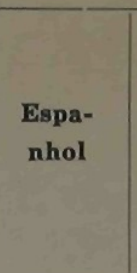 & Francess & Ingles & talalano & Latim & 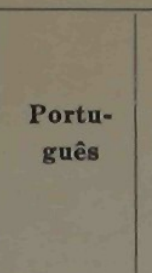 & 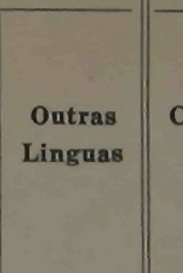 & Compra & Doaşäo & Permata I, & 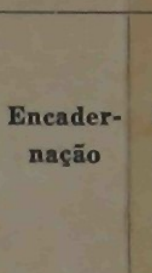 & 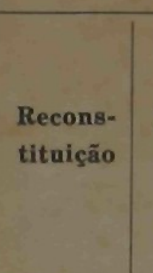 & 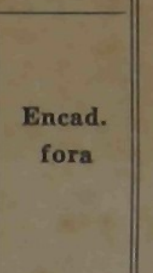 & \\
\hline 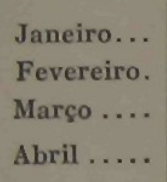 & $\begin{array}{c}423 \\
721 \\
804 \\
1.132\end{array}$ & $\begin{array}{l}2 \\
206 \\
205 \\
181\end{array}$ & $\begin{array}{l}199 \\
293 \\
229 \\
290\end{array}$ & $\begin{array}{l}10 \\
6 \\
2\end{array}$ & $\begin{array}{l}167 \\
180 \\
160 \\
117\end{array}$ & $\begin{array}{l}\frac{4}{18} \\
18 \\
65 \\
65\end{array}$ & $\begin{array}{l}63 \\
49 \\
47 \\
75\end{array}$ & $\begin{array}{l}20 \\
46 \\
63 \\
48\end{array}$ & $\begin{aligned} 566 \\
899 \\
865 \\
1.095\end{aligned}$ & $\begin{array}{r}1 \\
3 \\
4 \\
11\end{array}$ & 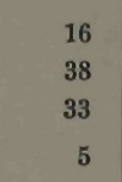 & $\begin{array}{l}1 \\
15 \\
24 \\
11\end{array}$ & $\begin{array}{r}3 \\
2 \\
5 \\
10\end{array}$ & $\overline{7}$ & $\begin{array}{c}64 \\
92 \\
98 \\
62 \\
62\end{array}$ & \begin{tabular}{l|l}
20 \\
23 \\
25 \\
75
\end{tabular} & 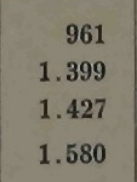 & $\begin{array}{l}1.989 \\
1.982 \\
1.928 \\
1.998\end{array}$ & $\begin{array}{l}29 \\
43 \\
45 \\
82\end{array}$ & $\begin{array}{c}37 \\
63 \\
55 \\
10\end{array}$ & $\begin{array}{c}277 \\
56 \\
36 \\
60\end{array}$ & $\begin{array}{l}223 \\
199 \\
194 \\
220\end{array}$ & $\begin{array}{c}37 \\
8 \\
17 \\
6\end{array}$ & $\begin{array}{l}28 \\
31 \\
38 \\
99\end{array}$ & $\begin{aligned} 22 \\
1 \\
1 \\
27\end{aligned}$ & $\begin{array}{l}\text { 6.114 } \\
1.1 .09 \\
1.158\end{array}$ & $\begin{array}{l}\bar{z} \\
\bar{z}\end{array}$ & $\begin{array}{r}5 \\
7 \\
6 \\
14\end{array}$ & $\begin{array}{l}\frac{8}{32} \\
128 \\
47 \\
77\end{array}$ & $\begin{aligned} 28 \\
19 \\
5 \\
2\end{aligned}$ & $\begin{array}{l}120 \\
\text { 123 } \\
\text { s. } \\
67\end{array}$ & $\begin{array}{c}4 \\
8 \\
18 \\
26\end{array}$ & $\frac{47}{56}$ & 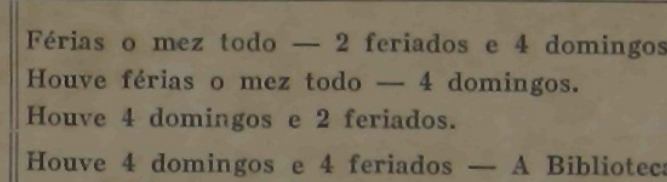 \\
\hline 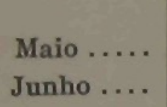 & $\begin{array}{l}2.437 \\
2.089\end{array}$ & $\begin{array}{l}302 \\
259 \\
259\end{array}$ & $\frac{545}{555}$ & $\begin{array}{c}13 \\
8\end{array}$ & 染65 & 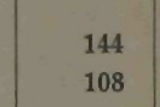 & 199 199 & 帒9 & $\begin{array}{l}2.387 \\
2.010\end{array}$ & $\frac{7}{2}$ & $\frac{3}{2}$ & ${ }_{8}^{7}$ & $\begin{array}{c}13 \\
3\end{array}$ & $\overline{6}$ & $\begin{array}{l}85 \\
66\end{array}$ & 想 & $\begin{array}{l}3.450 \\
2.802\end{array}$ & 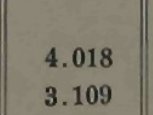 & $\begin{array}{l}115 \\
102\end{array}$ & 193 & $\underset{141}{141}$ & $\begin{array}{l}523 \\
567\end{array}$ & $\begin{array}{c}13 \\
7\end{array}$ & 每5 & $\begin{array}{l}70 \\
37\end{array}$ & $\begin{array}{l}2.578 \\
2.140\end{array}$ & $=$ & ${ }_{28}^{23}$ & 集9 & $\underset{\substack{61 \\
22}}{2}$ & $\begin{array}{c}87 \\
69\end{array}$ & $\begin{array}{l}17 \\
14\end{array}$ & 100 & 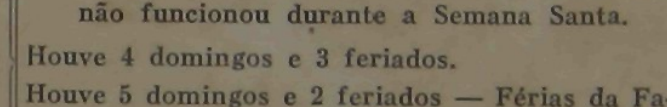 \\
\hline Julho... & ${ }_{726}$ & ${ }_{197}$ & 500 & $?$ & ${ }_{190}$ & ${ }_{44}$ & 9 & ${ }_{75}$ & 773 & ${ }_{13}$ & 11 & 4 & - & 4 & 88 & ${ }_{85}$ & 1.389 & ${ }_{1.641}$ & 40 & ${ }_{63}$ & ${ }^{n}$ & ${ }^{246}$ & 19 & 50 & ${ }_{28}$ & 975 & - & ${ }^{54}$ & 35 & 40 & ${ }_{81}$ & 58 & ${ }_{162}$ & 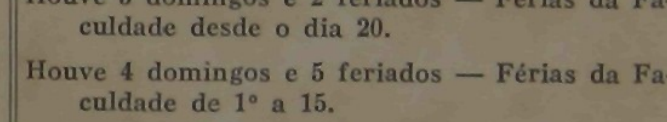 \\
\hline 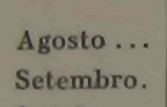 & $\begin{array}{c}2.008 \\
2.176 \mathrm{~S}\end{array}$ & 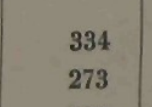 & 然野 & $\begin{array}{c}26 \\
14\end{array}$ & 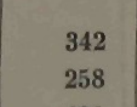 & 勇的 & 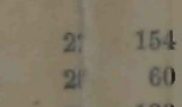 & $\begin{array}{l}118 \\
107 \\
107\end{array}$ & 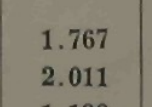 & ${ }_{24}^{23}$ & $\begin{array}{l}18 \\
15\end{array}$ & 14 & $\begin{array}{l}18 \\
18 \\
18\end{array}$ & $?$ & 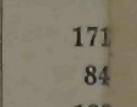 & 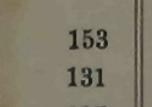 & $\begin{array}{l}2.910 \\
2.804\end{array}$ & \begin{tabular}{l|l}
3.223 \\
3.056
\end{tabular} & ${ }_{97}^{91}$ & 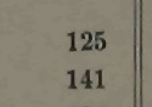 & $\begin{array}{l}173 \\
170\end{array}$ & 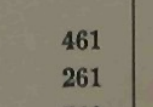 & $\begin{array}{c}31 \\
30\end{array}$ & $\begin{array}{c}95 \\
4 \\
4\end{array}$ & $\begin{array}{c}89 \\
68 \\
68\end{array}$ & 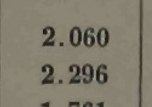 & $-\frac{1}{-}$ & $\begin{array}{l}25 \\
12\end{array}$ & ${ }_{42}^{29}$ & 器 & $\begin{array}{c}80 \\
90\end{array}$ & ${ }_{21}^{20}$ & $\begin{array}{c}1166 \\
248\end{array} ;$ & 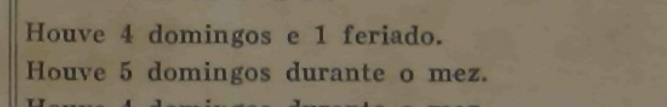 \\
\hline 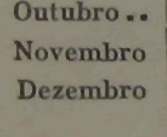 & 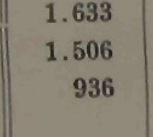 & 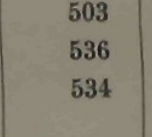 & $\begin{array}{l}1.104 \\
\text { 1. } 014 \\
788\end{array}$ & $\begin{array}{c}3 \\
4 \\
16\end{array}$ & 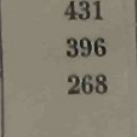 & $\begin{array}{l}101 \\
109 \\
45\end{array}$ & 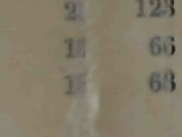 & 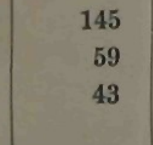 & 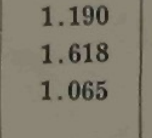 & $\begin{array}{l}\frac{1}{14} \\
22\end{array}$ & $\begin{array}{l}51 \\
71 \\
40\end{array}$ & $\begin{array}{l}15 \\
8 \\
6\end{array}$ & $\begin{array}{l}\begin{array}{r}13 \\
9 \\
5\end{array} \\
0\end{array}$ & $\begin{array}{l}7 \\
6 \\
3\end{array}$ & $\begin{array}{c}180 \\
65 \\
90 \\
90\end{array}$ & $\begin{array}{c}197 \\
90 \\
60\end{array}$ & $\begin{array}{l}2.490 \\
2.527 \\
1.37\end{array}$ & 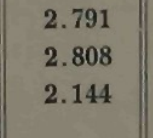 & $\begin{array}{c}79 \\
89 \\
62\end{array}$ & $\begin{array}{l}12 \\
133 \\
95\end{array}$ & $\begin{array}{c}85 \\
89 \\
65 \\
65\end{array}$ & $\begin{array}{l}512 \\
\text { s54 } \\
189\end{array}$ & $\begin{array}{l}\frac{1}{18} \\
24 \\
15\end{array}$ & $\begin{array}{c}\frac{6}{69} \\
67 \\
37\end{array}$ & $\begin{array}{c}\text { 类 } \\
39 \\
33\end{array}$ & 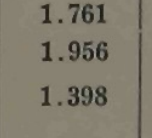 & $\begin{array}{r}2 \\
-1\end{array}$ & $\begin{array}{l}\frac{11}{6} \\
19\end{array}$ & $\begin{array}{c}31 \\
31 \\
118\end{array}$ & $\begin{array}{c}35 \\
33 \\
30\end{array}$ & $\begin{array}{l}67 \\
7 \\
93 \\
93\end{array}$ & $\begin{array}{l}\frac{1}{19} \\
15 \\
38\end{array}$ & $\begin{array}{l}=1 \\
=\end{array}$ & 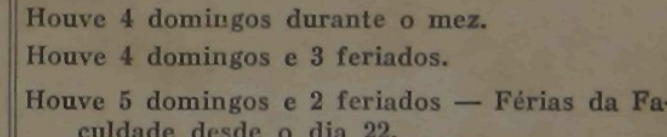 \\
\hline \multirow[t]{2}{*}{ Totais } & 16.591 & $\mid$\begin{tabular}{|l|}
$\mid 4.013$ \\
28.
\end{tabular} & $\begin{array}{l}7.634 \\
347\end{array}$ & 109 & 3.147 & ${ }_{922}$ & 16 1.052 & 1.036 & 16.246 & ${ }_{13}^{13}$ & 303 & ${ }^{118}$ & 89 & ${ }^{44}$ & 1.128 & 1.033 & 25.476 & 30.076 & - & - & 995 & 3.899 & 225 & 790 & 461 & 19.132 & 4 & 210 & $\frac{780}{342}$ & 3.3 $\|$ & 1.033 & $\frac{258}{2.070}$ & 79 & \\
\hline & \multicolumn{34}{|c|}{ PERIODO DE 2 DE SETEMBRO A 31 DE DEZEMBRo DE 1935. (Periodo noturno) } \\
\hline Setembro. & 665 & ${ }_{107}$ & ${ }_{191}$ & - & ${ }_{112}$ & 27 & 35 & 44 & ${ }_{527}$ & 6 & 5 & 5 & $|7|$ & ${ }^{2}$ & 32 & ${ }^{58} \|$ & ${ }^{868}$ & | 955|| & 39 & ${ }^{43} \|$ & ${ }^{66}$ & 99 & ${ }^{4}$ & ${ }^{22}$ & so & 657 & - & - & & & - & - & & 05 dom, a Bib. tumcionour \\
\hline Outuro.. & 246 & 202 & 207 & - & 102 & ${ }_{15}$ & ${ }^{24}$ & 25 & ${ }^{224}$ & 1 & ${ }_{33}$ & 4 & 2 & 2 & 50 & 56 & ${ }_{541}$ & 581 & 20 & 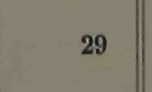 & 12 & 117 & 3 & ${ }_{14}^{14}$ & - & 395 & - & - & - & - & - & - & - & 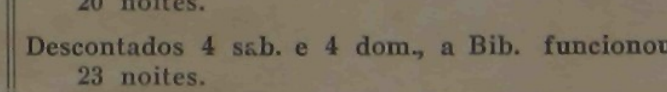 \\
\hline Novembro & 264 & ${ }^{229}$ & 52 & - & 116 & 39 & ${ }_{28}$ & ${ }^{24}$ & 293 & 1 & 54 & 1 & - & - & 19 & ${ }_{41}$ & 620 & 687 & 26 & 28 & 18 & 126 & 4 & 6 & 3 & 463 & - & - & - & - & - & - & & tem 4 sabe, 4 dom. e 3 fer, a Bib. funcionor \\
\hline Dezembro & 179 & ${ }_{174}$ & ${ }_{117}^{11}$ & - & ${ }_{76}$ & ${ }_{23}$ & 37 & ${ }_{10}$ & ${ }^{222}$ & - & ${ }_{26}$ & 1 & - & 1 & ${ }_{11}$ & 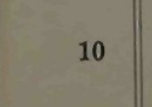 & 417 & ${ }^{486}$ & ${ }_{17}$ & ${ }_{22}$ & 15 & ${ }_{64}^{64}$ & 5 & 3 & 7 & ${ }_{323}$ & - & - & - & - & - & - & - & 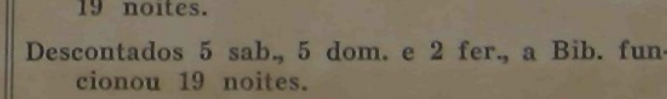 \\
\hline Totais & 1.354 & $\frac{712}{2.63}$ & 667 & 1- & 406 & ${ }_{104}$ & i) 121 & ${ }^{103}$ & 1266 & 8 & ${ }_{118}$ & ${ }^{11}$ & ${ }^{9}$ & 5 & ${ }_{112}^{12}$ & 165 & 246 & 2709 & - & - & 101 & 406 & 16 & 45 & 40 & 1838 & & & & & & & & \\
\hline & & & & & & & & & & & & & & & & & & $\begin{array}{l}\text { Lregerado CA } \\
\text { da }\end{array}$ & $\begin{array}{l}\text { SDDo o o } \\
\text { Expedien }\end{array}$ & & & & & & & & & & & & & & & \\
\hline
\end{tabular}




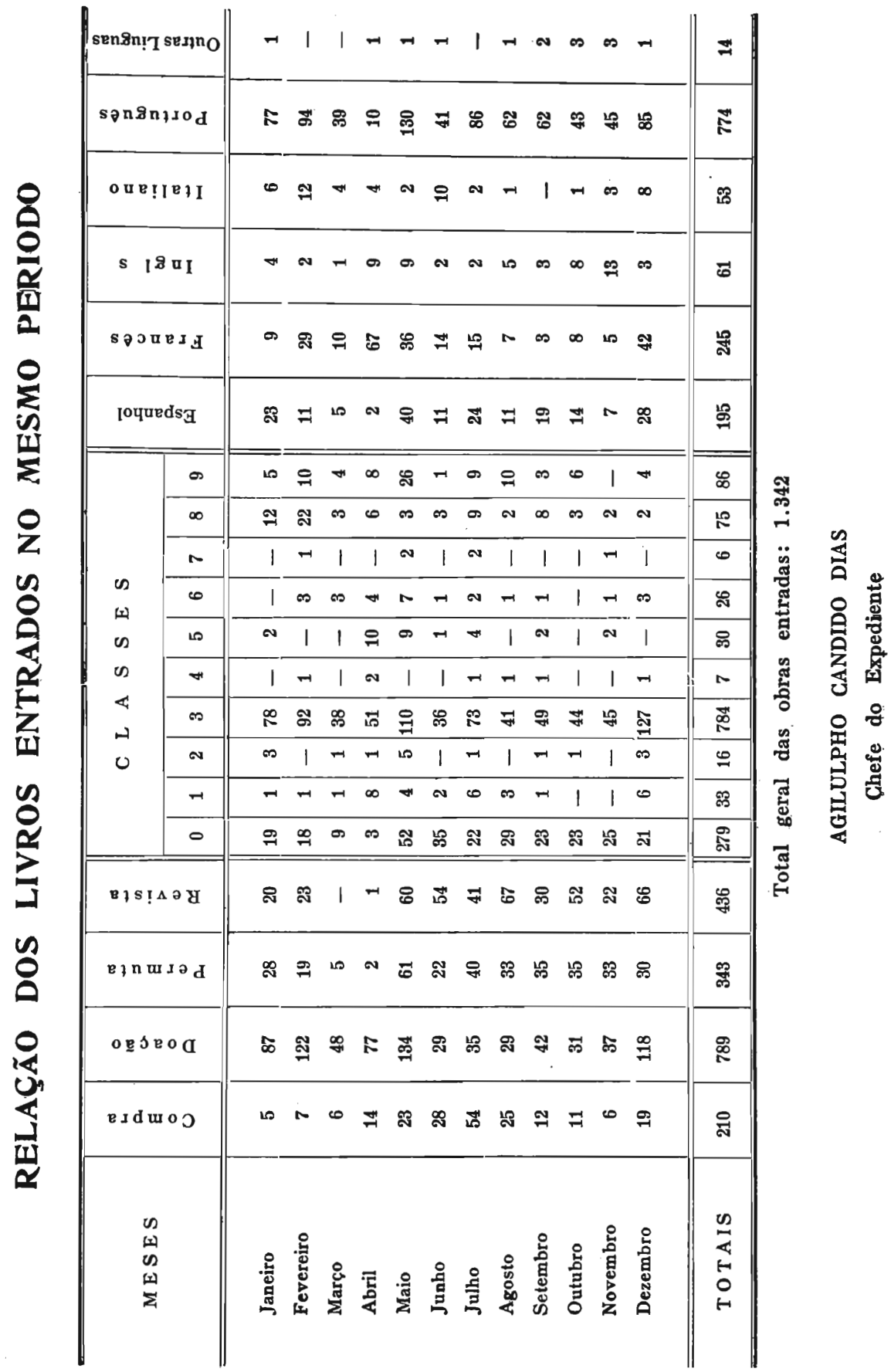

